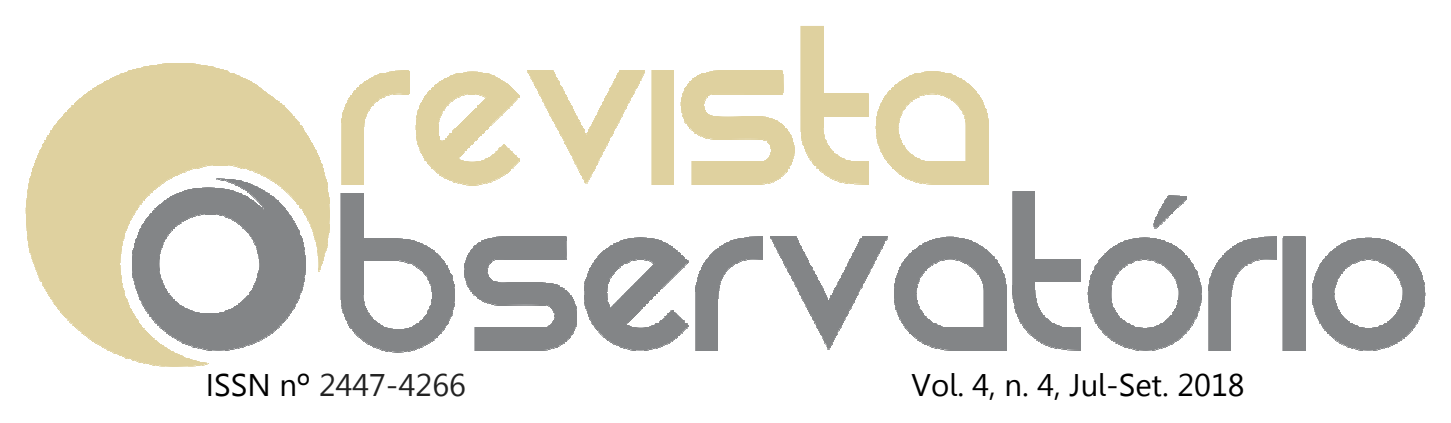

DOI: https://doi.org/10.20873/uft.2447-4266.2018v4n4p571

\section{INSTITUCIONALIZAÇÃO DA PESQUISA SOBRE CRIANÇA E ADOLESCENTE EM \\ JORNALISMO E EM \\ COMUNICAÇÃO NOS ANOS}

1990 E 2000
CHILDREN AND ADOLESCENTS CONSOLIDATION RESEARCH IN JOURNALISM AND COMMUNICATION SCIENCE IN 1990 AND 2000 DECADES

INSTITUCIONALIZACIÓN DE LA INVESTIGACIÓN SOBRE NIÑO Y ADOLESCENTE EN PERIODISMO Y COMUNICACIÓN EN LOS AÑOS 1990 Y 2000

\author{
Robson Dias ${ }^{1}$ \\ Daniel Gonçalves de Ploveira ${ }^{2}$ \\ Victor Márcio Laus Reis Gomes ${ }^{3}$ \\ João José de Azevedo Curvello ${ }^{4}$ \\ Luiza Mônica de Assis Silva ${ }^{5}$ \\ Alberto Marques Silva ${ }^{6,7}$
}

\title{
RESUMO
}

O estudo da criança e do adolescente em seus vínculos com o noticiário midiático tem dimensões bem específicas na Teoria da Notícia. No entanto, não

\footnotetext{
1 Jornalista, mestre e doutor em Comunicação. Professor e pesquisador do mestrado em Comunicação da Universidade Católica de Brasília (PPGSSCOM/UCB). Email: rbsn.dias@gmail.com.

${ }^{2}$ Doutorando em Comunicação Social pela Universidade de Brasília (UnB) e professor no Instituto de Educação Superior de Brasília (IESB). E-mail: daniel 890 unb@gmail.com.

${ }_{3}^{3}$ Publicitário, mestre em Administração e doutor em Comunicação. Professor e pesquisador do PPGSSCOM/UCB. E-mail: victorgome.s@gmail.com.

4 Jornalista, mestre e doutor em Comunicação. Professor e pesquisador do curso de Comunicação Organizacional (UnB). E-mail: joao curvello@gmail.com.

${ }^{5}$ Jornalista e doutora em Psicologia Social, do Trabalho e das Organizações (PSTO). Professora e pesquisadora do PPGSSCOM/UCB. E-mail: luizaassis@uol.com.br.

${ }^{5}$ Doutor em Comunicação pela Universidade de Brasília (UnB). Atualmente é editor da Esferas, revista dos programas de pós-graduação do Centro-oeste. Email: alberto.marque.s@gmail.com.

${ }^{7}$ Endereço de contato dos autores (por correio): Universidade Católica de Brasília. Campus I QS 07 - Lote 01 - EPCT - Águas Claras - Brasília - DF CEP: 71966-700, Barsil.
} 


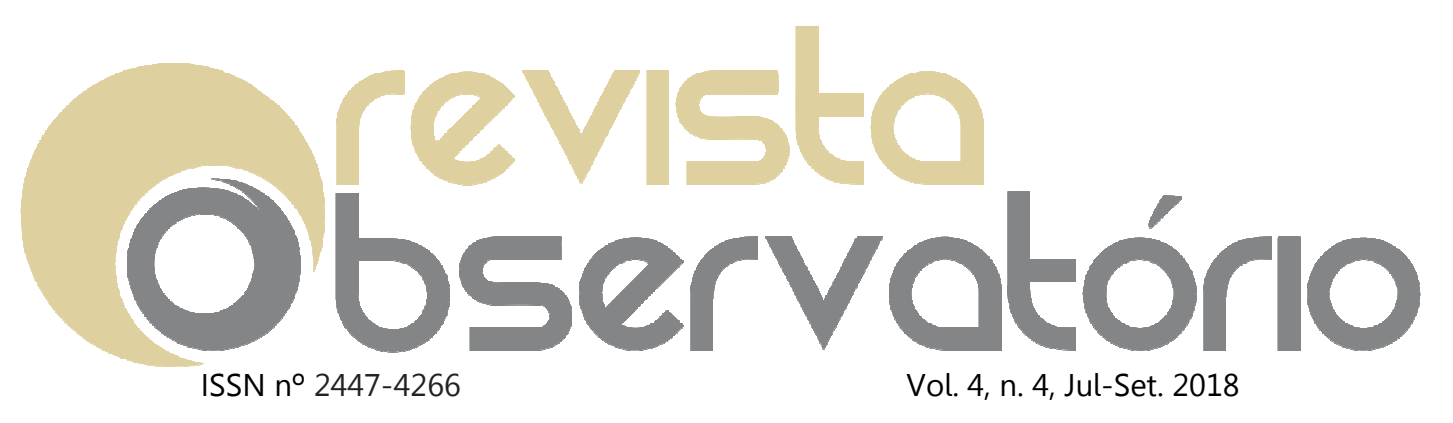

DOI: https://doi.org/10.20873/uft.2447-4266.2018v4n4p571

são apenas pesquisadores do Jornalismo e da Comunicação que se interessam pelo tema. Antes da institucionalização desse tipo de estudo na Comunicação, outras áreas versaram sobre o tema: Educação, História, Sociologia, Biblioteconomia, Psicologia Social, Serviço Social e até Ciências da Saúde. Este artigo inventaria 37 dissertações e 8 teses fazendo um balanço da pesquisa sobre o tema. O intuito é de munir pesquisadores que se interessem pela cronologia de estudo do tema nas Ciências Sociais Aplicadas e pela sua institucionalização na Ciência em Jornalismo e em Comunicação no Brasil.

PALAVRAS-CHAVE: Criança. Adolescente. Jornalismo. Comunicação. Notícia.

\begin{abstract}
Children and adolescents study has specific dimensions in News Theory. However, not only Journalism and Communication researchers are interested in the subject. Before Journalism and Communication media approachs research institutionalization other areas were about to investigate child and teenager on media frame: Education, History, Sociology, Library Science, Social Psychology, Social Work and to Health Sciences. This article identifies 37 lectures and 8 theses and analyses their approaches as a chronological science history in Social, Journalism and Communication areas in Brazil. The aim is to equip researchers all over the world who are interested in childhood and adolescence in media frame.
\end{abstract}

KEYWORDS: Child. Teenager. Journalism. Communication. News.

\title{
RESUMEN
}

El estudio del niño y del adolescente en sus vínculos con el noticiero mediático tiene dimensiones bien específicas en la Teoría de las Noticias. Sin embargo, no son sólo investigadores del periodismo y de la comunicación que se interesan por el tema. Antes de la institucionalización de este tipo de estudio en la Comunicación, otras áreas versaron sobre el tema: Educación, Historia, Sociología, Biblioteconomía, Psicología Social, Servicio Social e incluso Ciencias de la Salud. Este artículo inventaría 37 disertaciones y 8 tesis haciendo un 


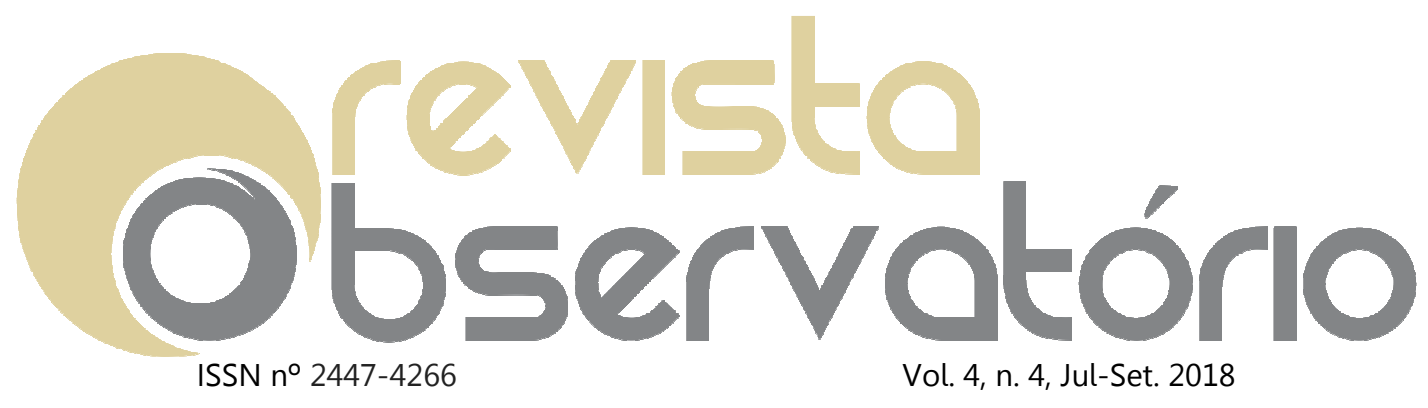

DOI: https://doi.org/10.20873/uft.2447-4266.2018v4n4p571

balance de la investigación sobre el tema. La intención es de munir investigadores que se interesen por la cronología de estudio del tema en las Ciencias Sociales Aplicadas y por su institucionalización en la Ciencia en Periodismo y en Comunicación en Brasil.

PALABRAS CLAVE: Niño. Adolescente. Periodismo. Comunicación. Noticias.

Recebido em: 12.11.2017. Aceito em: 16.01.2017. Publicado em: 29.06.2018. 


\section{Observatório \\ ISSN n 2447-4266 \\ Vol. 4, n. 4, Jul-Set. 2018}

DOI: https://doi.org/10.20873/uft.2447-4266.2018v4n4p571

\section{INTRODUÇÃO}

Trata-se de um estudo histórico, cronológico, descritivo, de caráter inventariante e quantiqualitativamente analítico por meio de análise de conteúdo. O material empírico da pesquisa bibliográfica versa exclusivamente sobre teses e dissertações. $O$ corpus é de 45 pesquisas: 37 dissertações e 8 teses (Quadro 1).

Quadro 1 - Corpus de teses e dissertações por década (1995-2009)

\begin{tabular}{|c|c|c|}
\hline Região & Dissertações & Teses \\
\hline Anos 1990 & 7 & 1 \\
\hline Anos 2000 & 30 & 7 \\
\hline
\end{tabular}

Fonte: Elaborado pelos autores

Tem como justificativa a institucionalização da pesquisa sobre criança e adolescente a partir de arcabouço teórico que verifique as (in)variáveis relativas à área de Comunicação, do Jornalismo ou mesmo tópicos da Teoria da Notícia (SOUSA, 2002; TRAQUINA, 1993), além de Agendamento, Newsmaking, ValoresNotícia, critérios de Noticiabilidade (dentre outros constructos em Warren Breed, Robert Hackett, Stuart Hall, Harvey Molotch e Marilyn Lester, Michael Schudson, John Soloski, Gaye Tuchman, David White, Philip Schlesinger). O leitor perceberá este perfil de pesquisa se consolidando no meio dos anos 2000. No entanto, nos anos 1990, as primeiras abordagens utilizavam checagens com base em memória, em historicidade, em representações sociais, dentre outros. Sempre apontando para o noticiário e o papel do emissor, a partir das categorias: mídia, jornalismo, veículo de comunicação ${ }^{8}$. Em suma, o emissor que

\footnotetext{
${ }^{8}$ Aqui, termo guarda-chuva em relação aos suportes: impresso, rádio, TV, internet.
} 


\section{Observotório}

DOI: https://doi.org/10.20873/uft.2447-4266.2018v4n4p571

produz cognição, sentido e que é aplicado por várias áreas do conhecimento de dada forma a ser checada na análise qualitativa.

O estudo demarca geograficamente focos de produção desse corpus:

Quadro 2 - Produção de teses e dissertações por região (1995-2009)

\begin{tabular}{|c|c|c|c|}
\hline Região & Dissertações & Teses & Total \\
\hline Sudeste & 24 & 6 & 30 \\
\hline Centro-Oeste & 6 & - & 6 \\
\hline Nordeste & 5 & - & 5 \\
\hline Sul & 3 & 1 & 4 \\
\hline
\end{tabular}

Fonte: Elaborado pelos autores

Também identifica os picos de produção e a posiciona no tempo:

Quadro 3 - Teses e dissertações do corpus: anos mais produtivos (1995-2009)

\begin{tabular}{|c|c|}
\hline Anos mais produtivos & $\begin{array}{c}\text { Quantidade de trabalhos por } \\
\text { ano }\end{array}$ \\
\hline 2008,2005 & 9 \\
\hline 2004 & 4 \\
\hline $1996,2001,2002$ & 3 \\
\hline $1999,2000,2003,2007,2009$ & 2 \\
\hline $1995,1997,1998,2006$ & 1 \\
\hline
\end{tabular}

Fonte: Elaborado pelos autores 


\section{Observotório \\ ISSN n² 2447-4266 \\ Vol. 4, n. 4, Jul-Set. 2018}

DOI: https://doi.org/10.20873/uft.2447-4266.2018v4n4p571

Quadro 4 - Teses e dissertações do corpus: cronologia de trabalhos editados por ano (19952009)

\begin{tabular}{|c|c|c|}
\hline Ano & Autor & Quantidade \\
\hline 1995 & Bastos & 1 \\
\hline 1996 & A. Costa, Santos, Figueiredo & 3 \\
\hline 1997 & Frontana & 1 \\
\hline 1998 & Trindade & 1 \\
\hline 1999 & J. Souza, M. Souza & 2 \\
\hline 2000 & M. Pereira, Mattos & 2 \\
\hline 2001 & Andrade, Faraone & 3 \\
\hline 2002 & Jacob, Rebechi, Guarnieri \\
\hline 2003 & Duarte, Azevedo & 2 \\
\hline 2004 & Freitas, Nazareth, Assis, Andreotti & 4 \\
\hline 2005 & $\begin{array}{c}\text { Andrade, Câmara, Landini, Lessa, Raposo, } \\
\text { Lima, F. Pereira, Ribeiro, Bonfim }\end{array}$ & 9 \\
\hline 2006 & Brasiliense & 2 \\
\hline 2007 & Santos, Pistolato, Campos, Bizzo & 9 \\
\hline 2008 & Anselmo, Reimberg, Cerqueira & 2 \\
\hline 2009 & Fontes, Jilva & 2 \\
\hline
\end{tabular}

Fonte: Elaborado pelos autores

E também as áreas que mais se interessaram em abordagens dentro do escopo do corpus deste artigo: 


\section{Observotório}

DOI: https://doi.org/10.20873/uft.2447-4266.2018v4n4p571

Quadro 5 - Teses e dissertações do corpus: trabalhos editados por área (1995-2010)

\begin{tabular}{|c|c|c|}
\hline Área & Autor & $\begin{array}{c}\text { Quantidad } \\
\text { e }\end{array}$ \\
\hline Comunicação & $\begin{array}{c}\text { M. Souza (1999), M. Pereira (2000), Mattos (2000), } \\
\text { Faraone (2001), Guarnieri (2002), Jacob (2002), Duarte } \\
\text { (2003), Azevedo (2003), Câmara (2005), Lessa (2005), } \\
\text { Raposo (2005), Lima (2005), F. Pereira (2005), Ribeiro } \\
\text { (2005), Bonfim (2005), Brasiliense (2006), Nunes (2007), } \\
\text { J. Silva (2008), Farah (2008), Mora (2008), Oliveira } \\
\text { (2008), Dias (2008), Santos (2008), Pistolato (2008), } \\
\text { Anselmo (2009), Reimberg (2009), Cerqueira (2009) }\end{array}$ & \\
\hline Psicologia & Andrade (2001), Freitas (2004), Nazareth (2004), & \\
\hline Andrade (2005), Bizzo (2008) & 5 \\
\hline História & A. Costa (1996), Frontana (1997), Trindade (1998), J. \\
Souza (1999), Rebechi (2002) & 5 \\
\hline Educação & Bastos (1995), Assis (2004), Andreotti (2004) & 3 \\
\hline Sociologia & Santos (1996), Landini (2005) & 1 \\
\hline $\begin{array}{c}\text { Ciências } \\
\text { Sociais }\end{array}$ & Kraemer (2008) & 1 \\
\hline $\begin{array}{c}\text { Biblioteconomi } \\
\text { a }\end{array}$ & Figueiredo (1996) & 1 \\
\hline $\begin{array}{c}\text { Ciências da } \\
\text { Saúde }\end{array}$ & Campos (2008) & 1 \\
\hline
\end{tabular}

Fonte: Elaborado pelos autores

E também a marcação de quais Instituições de Ensino Superior (IES) produziram em maior quantidade:

\footnotetext{
${ }^{9}$ Não identificado se Ciências Sociais em ramo específico: Sociologia, Antropologia ou Política, na PUCRS.
} 


\section{Observotório \\ ISSN n० 2447-4266 \\ Vol. 4, n. 4, Jul-Set. 2018}

DOI: https://doi.org/10.20873/uft.2447-4266.2018v4n4p571

Quadro 6: Produção de teses e dissertações por IES (1995-2009)

\begin{tabular}{|c|c|c|c|}
\hline IES & Dissertações & Teses & Quantidade \\
\hline USP & $\begin{array}{c}\text { Frontana (1997), Farone (2001), } \\
\text { Guarnieri (2002), Jacob (2002), } \\
\text { Azevedo (2003), Lessa (2005), } \\
\text { Pereira (2005), Reimberg (2009), }\end{array}$ & Landini (2005) & 9 \\
\hline PUCSP & $\begin{array}{l}\text { A. Costa (1996), J. Souza (1999), } \\
\text { Freitas (2004), Nazareth (2004), } \\
\text { Bizzo (2008) }\end{array}$ & $\begin{array}{l}\text { Andrade (2001), } \\
\text { Andrade (2005) }\end{array}$ & 7 \\
\hline UnB & $\begin{array}{c}\text { M. Pereira (2000), Lima (2005), } \\
\text { Bonfim (2005), Mora (2008), Dias } \\
\text { (2008), Oliveira (2008) }\end{array}$ & - & 6 \\
\hline UFPE & $\begin{array}{c}\text { Raposo (2005), J. Silva (2008), } \\
\text { Santos (2008) }\end{array}$ & - & 3 \\
\hline UFRJ & M. Souza (1999), Mattos (2000) & Duarte (2003) & 3 \\
\hline UFF & Bastos (1995), Brasiliense (2006) & - & 2 \\
\hline PUCRIO & Câmara (2005), Cerqueira (2009) & - & 2 \\
\hline UFMG & Campos (2008) & Assis (2004) & 2 \\
\hline UNESP & Ribeiro (2005) & - & 1 \\
\hline Mackenzie & Rebechi (2002) & - & 1 \\
\hline USM & Nunes (2007) & - & 1 \\
\hline UNIMAR & Pistolato (2008) & - & 1 \\
\hline UNICAMP & - & Andreotti (2004) & 1 \\
\hline UFC & Santos (1996) & - & 1 \\
\hline UFPB & Figueiredo (1996) & - & 1 \\
\hline PUCRS & Kraemer (2008) & - & 1 \\
\hline UFPR & - & Trindade (1998) & 1 \\
\hline
\end{tabular}




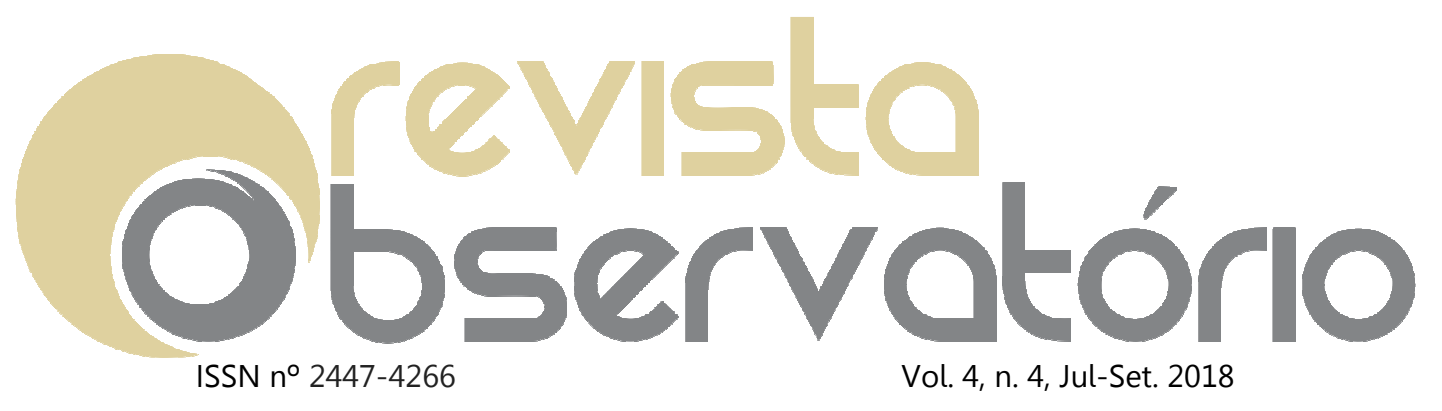

DOI: https://doi.org/10.20873/uft.2447-4266.2018v4n4p571

\begin{tabular}{|c|c|c|c|}
\hline UTP & Farah (2008) & - & 1 \\
\hline UFRGS & Anselmo (2009) & - & 1 \\
\hline
\end{tabular}

Fonte: Elaborado pelos autores

São elementos desta abordagem analítica qualitativa:

- Produção de teses e dissertações sobre criança e adolescente enquadrados nas categorias: jornalismo, mídia, veículos de comunicação (19952009), segundo escopo - Quadro 6. Excluem-se abordagens que utilizem o noticiário, reportagens e matérias, como forma de educação de dada comunidade ou grupo (muito comum na Educação)

- Nos parágrafos e seções: ordem cronológica de apresentação dos autores (por ano), excluindo-se a hierarquização deles em um mesmo ano (exemplo: 9 trabalhos sobre o tema em 2008 e a precedência da banca de defesa no mês x ou no mês y).

- A tentativa da análise qualitativa de agrupamento de gerações ou do espírito de um tempo (por ano, por décadas, por região, por disciplina, por PPG), ou seja, marcações que possam ajudar o pesquisador interessado a contextualizar a produção.

São elementos desta abordagem analítica quantitativa:

\footnotetext{
○ Produção de teses e dissertações por IES (1995-2009) - Quadro 6

○ Produção de teses e dissertações por região (1995-2009) - Quadro 2

○ Produção de teses e dissertações por área (1995-2009) - Quadro 5

○ Produção de teses e dissertações por ano (1995-2009) - Quadro 3 e 4
} 


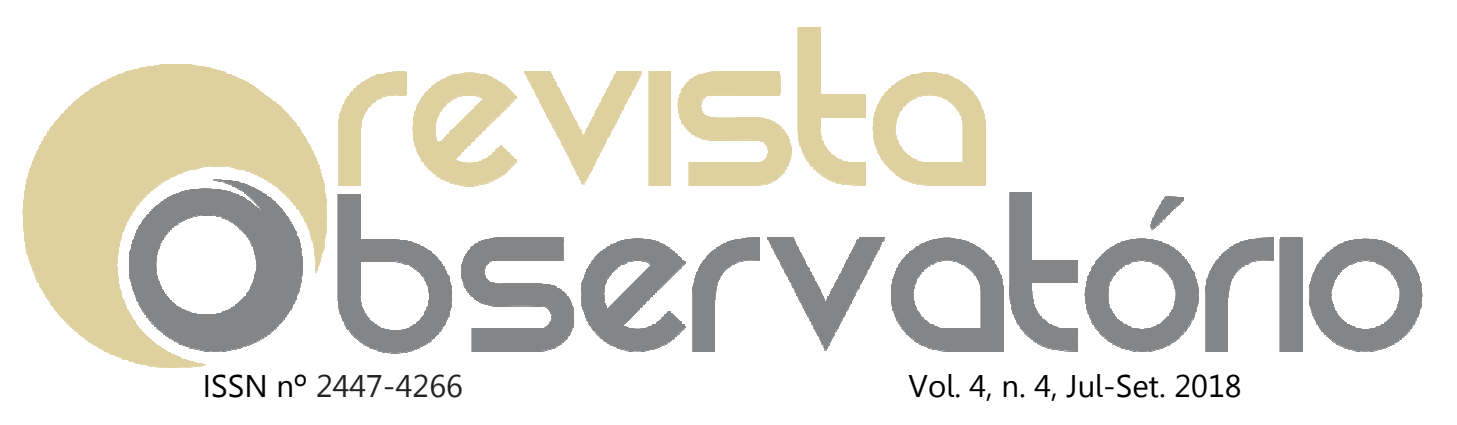

DOI: https://doi.org/10.20873/uft.2447-4266.2018v4n4p571

○ Produção de teses e dissertações por década (1995-2009) - Quadro 1

O trabalho tem corte temporal na década de 1990 - a partir de Bastos (1995), trabalho inaugural - e segue até o fim dos anos 2000: entendendo a contagem de década finalizando em 2009 (logo: 2000-2009). O material empírico acessado mediante comutação bibliográfica e livre acesso online (Banco de Teses da Capes - MEC/CAPES, Domínio Público - MEC, Biblioteca Digital de Teses e Dissertações do Instituto Brasileiro de Informação em Ciência e Tecnologia - MCTI/IBICT, Catálogo de Revistas em Comunicação e Resumos de Teses e Dissertações do Núcleo de Pesquisa em Informação, Tecnologias e Práticas Sociais - INFOTEC/ UFRGS).

Escopo: dissertações e teses em stricto sensu baseadas em palavraschave, resumos, títulos que possam dar condições de configurar a abordagem do tema da criança e do adolescente em objetos de estudo que toquem o campo do Jornalismo e da Comunicação, principalmente a partir das categorias de jornalismo, mídia, veículo de comunicação. As palavras-chave utilizadas para identificação dos trabalhos são: criança, adolescente, infância, adolescência, jornalismo, mídia, comunicação. De forma acessória, mas não como mecanismo de geração de insumos, foram utilizados Google Acadêmico, revistas OJS, indexadores online, diretório de grupos de pesquisa (DGP/CNPq) e plataforma lattes $(\mathrm{CNPq})$ com $\mathrm{o}$ intuito de checar perfis de revistas, orientadores e Programas de Pós-Graduação (PPGs) que pudessem contextualizar melhor a amostra. É importante salientar que nos interessam as abordagens com foco no emissor ${ }^{10}$ : mídia, jornalismo, veículo de comunicação, pauta enquadrada em dada matéria jornalística, conforme quadro 7 :

\footnotetext{
${ }^{10}$ Inclusos: abordagens da mensagem, de código, de canal que apontem para o polo do emissor.
} 


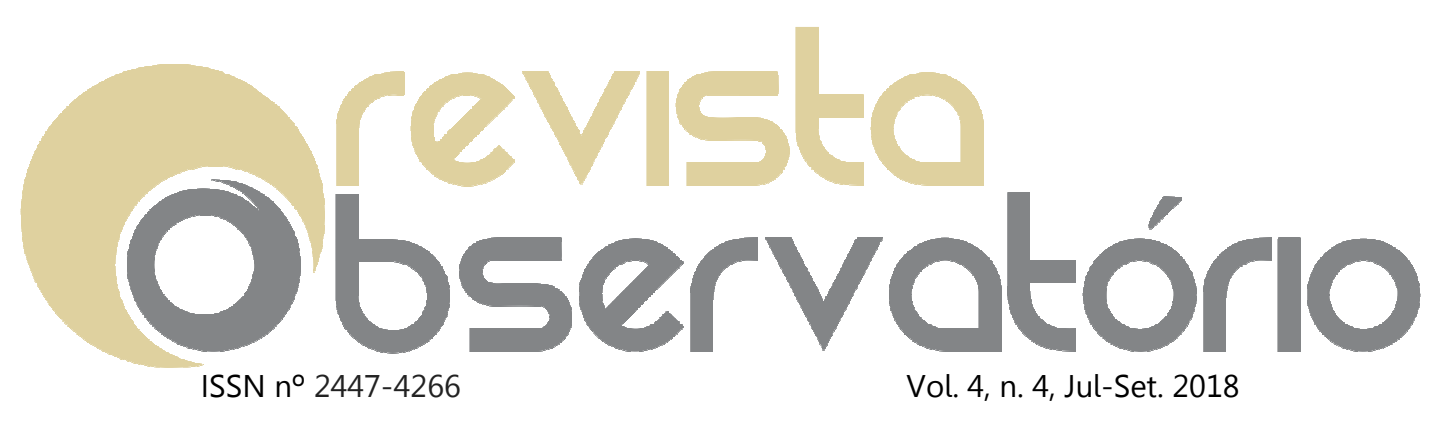

DOI: https://doi.org/10.20873/uft.2447-4266.2018v4n4p571

Quadro 7: Escopo de teses e dissertações sobre criança e adolescente que apontem para o polo do emissor (jornalismo, mídia, veículos de comunicação): (1995-2009)

\begin{tabular}{|c|c|c|c|c|c|}
\hline Autor & Ano & IES & Área & DT & Título \\
\hline Bastos & 1995 & UFF & Educação & $M$ & $\begin{array}{l}\text { O movimento de defesa da criança e } \\
\text { do adolescente: uma contribuição } \\
\text { para sua análise }\end{array}$ \\
\hline A. Costa & 1996 & PUCSP & História & $M$ & $\begin{array}{l}\text { O pão do corpo o pão da } \\
\text { inteligência e o pão do coração - o } \\
\text { lugar da criança na sociedade 1927- } \\
1990\end{array}$ \\
\hline Santos & 1996 & UFC & Sociologia & $M$ & $\begin{array}{l}\text { Meninas, sexo e espaço público: } \\
\text { análise do discurso jornalístico } \\
\text { cearense sobre a prostituiçâa infantil }\end{array}$ \\
\hline Figueiredo & 1996 & UFPB & $\begin{array}{l}\text { Biblioteconom } \\
\quad \text { ia }\end{array}$ & M & $\begin{array}{l}\text { Informação e cidadania: meninos de } \\
\text { rua no discurso da imprensa } \\
\text { paraibana }\end{array}$ \\
\hline Frontana & 1997 & USP & História & M & $\begin{array}{l}\text { Cotidiano de crianças e adolescentes } \\
\text { nas ruas da metrópole paulistana: } \\
\text { sob o fogo cruzado de posturas e } \\
\text { opiniões (1964-1965) }\end{array}$ \\
\hline Trindade & 1998 & UFPR & História & $\mathrm{D}$ & $\begin{array}{l}\text { Metamorfose de criança para menor: } \\
\text { Curitiba início do século XX }\end{array}$ \\
\hline J. Souza & 1999 & PUCSP & História & M & $\begin{array}{l}\text { Da infância desvalida d̀ infância } \\
\text { delinquente: Fortaleza (1865-1928) }\end{array}$ \\
\hline M. Souza & 1999 & UFRJ & Comunicação & M & $\begin{array}{l}\text { Infância de papel: análise do discurso } \\
\text { jornalístico sobre a infância na } \\
\text { imprensa brasileira }\end{array}$ \\
\hline M. Pereira & 2000 & UnB & Comunicação & M & $\begin{array}{l}\text { Condenados à Juventude: Um estudo } \\
\text { comparativo sobre a juvenilização no } \\
\text { jornalismo brasileiro }\end{array}$ \\
\hline Mattos & 2000 & UFRJ & Comunicação & M & $\begin{array}{llll}\begin{array}{l}\text { Adolescência, mídia } \\
\text { comunitária }\end{array} & \text { ação } \\
& & \end{array}$ \\
\hline Faraone & 2001 & USP & Comunicação & M & $\begin{array}{l}\text { Temas de cidadania em jornais } \\
\text { infantis - um estudo dos } \\
\text { suplementos A Gazetinha, Diário }\end{array}$ \\
\hline
\end{tabular}




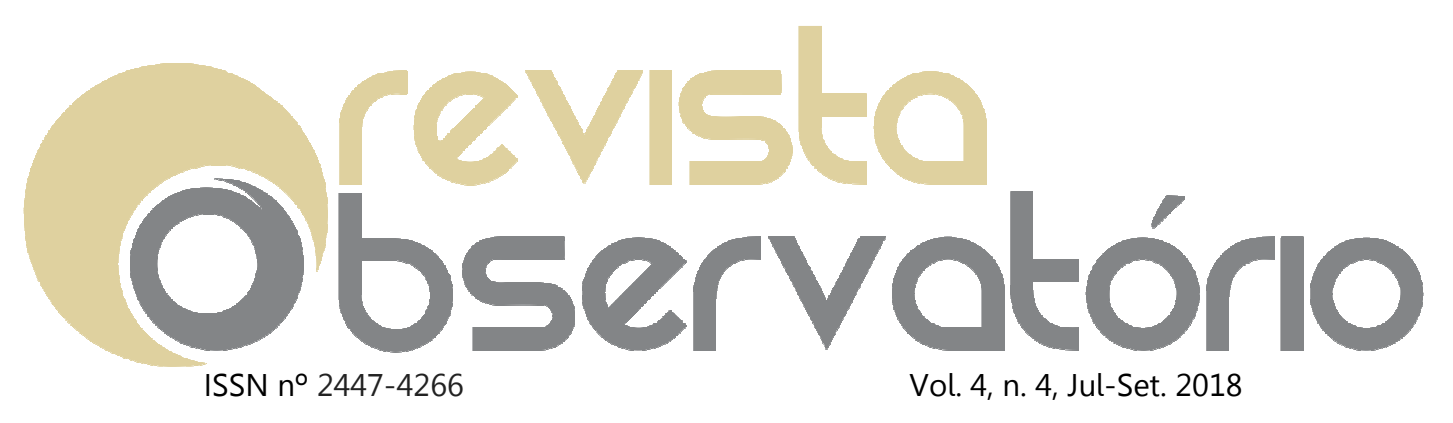

DOI: https://doi.org/10.20873/uft.2447-4266.2018v4n4p571

\begin{tabular}{|c|c|c|c|c|c|}
\hline & & & & & Criança, Estadinho e Folhinha \\
\hline Andrade & 2001 & PUCSP & Psicologia & $\mathrm{D}$ & $\begin{array}{l}\text { Prostituição infanto-juvenil e mídia: } \\
\text { estigmatização da pobreza e } \\
\text { ideologia }\end{array}$ \\
\hline Guarnieri & 2002 & USP & Comunicação & M & $\begin{array}{l}\text { Violência e imprensa. O tratamento } \\
\text { mediático da violência criminal } \\
\text { juvenil }\end{array}$ \\
\hline Jacob & 2002 & USP & Comunicação & M & $\begin{array}{l}\text { Infância na arena das palavras: as } \\
\text { relaçôes discursivas sobre a criança } \\
\text { de rua no jornal impresso }\end{array}$ \\
\hline Rebechi & 2002 & $\begin{array}{l}\text { Mackenzi } \\
\mathrm{e}\end{array}$ & História & M & $\begin{array}{l}\text { Agência de Notícias dos Direitos da } \\
\text { Infância ANDI - Um Estudo } \\
\text { Preliminar de uma Organização do } \\
\text { Terceiro Setor }\end{array}$ \\
\hline Duarte & 2003 & UFRJ & Comunicação & D & $\begin{array}{l}\text { Cidadania obstruída: jornais cariocas } \\
e \quad a \text { construção discursiva da } \\
\text { violência no Rio }\end{array}$ \\
\hline Azevedo & 2003 & USP & Comunicação & M & $\begin{array}{l}\text { Trabalho infantil, movimentos sociais } \\
\text { e imprensa: um olhar sobre o fazer } \\
\text { jornalistico }\end{array}$ \\
\hline Assis & 2004 & UFMG & Educação & $\mathrm{D}$ & $\begin{array}{l}\text { Psicologia, educação e reforma dos } \\
\text { costumes: liçóes da Selecta Cathólica } \\
\text { (1846-1847) }\end{array}$ \\
\hline Andreotti & 2004 & Unicamp & Educação & D & $\begin{array}{l}\text { A formação de uma geração: a } \\
\text { educação para a promoção social e o } \\
\text { progresso do país no jornal a voz da } \\
\text { infância da biblioteca infantil } \\
\text { municipal de São Paulo (1936-1950) }\end{array}$ \\
\hline Freitas & 2004 & PUCSP & Psicologia & $\mathrm{D}$ & $\begin{array}{l}\text { O tema trabalho infanto-juvenil na } \\
\text { mídia: uma interpretação ideológica }\end{array}$ \\
\hline Nazareth & 2004 & PUCSP & Psicologia & M & $\begin{array}{l}\text { O discurso da mídia sobre a } \\
\text { adolescente grávida: uma análise da } \\
\text { ideologia }\end{array}$ \\
\hline Andrade & 2005 & PUCSP & Psicologia & $\mathrm{D}$ & $\begin{array}{l}\text { A categoria "meninos de rua" na } \\
\text { mídia: uma interpretação ideológica }\end{array}$ \\
\hline
\end{tabular}




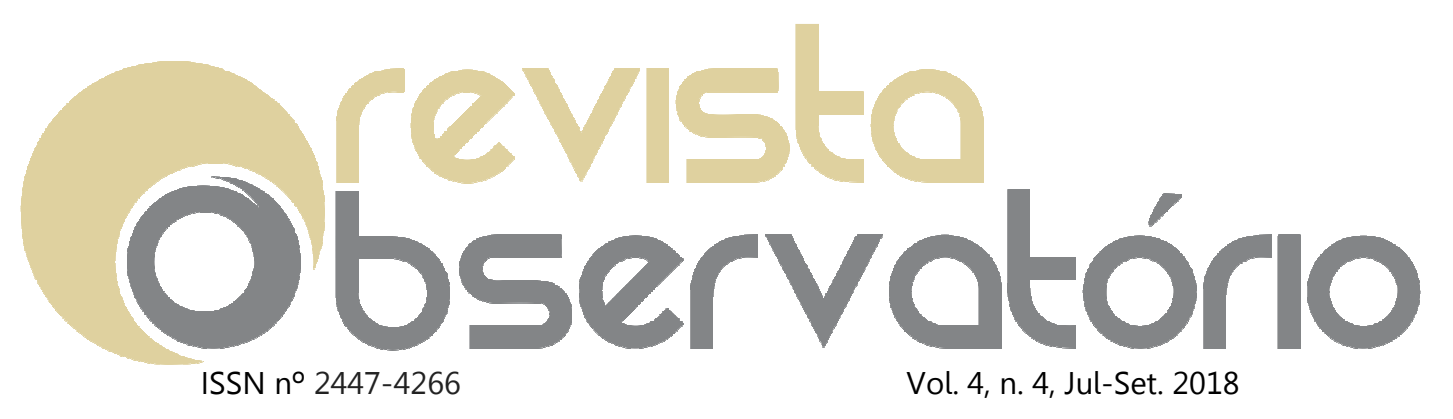

DOI: https://doi.org/10.20873/uft.2447-4266.2018v4n4p571

\begin{tabular}{|c|c|c|c|c|c|}
\hline Câmara & 2005 & PUCRIO & Comunicação & M & $\begin{array}{l}\text { Bala perdida, falas perdidas: o } \\
\text { discurso do jornalismo impresso } \\
\text { sobre a morte de Gabriela Prado }\end{array}$ \\
\hline Landini & 2005 & USP & Sociologia & $\mathrm{D}$ & $\begin{array}{l}\text { Horror, honra e direitos. Violência } \\
\text { sexual contra crianças e adolescentes } \\
\text { no século XX }\end{array}$ \\
\hline Lessa & 2005 & USP & Comunicação & M & $\begin{array}{l}\text { Sexualidades na mídia jovem: } \\
\text { informar, formar ou expor?Análise } \\
\text { dos discursos sobre sexualidades na } \\
\text { revista Capricho no período entre } \\
\text { 1992-1993 }\end{array}$ \\
\hline Raposo & 2005 & UFPE & Comunicação & M & $\begin{array}{l}\text { Comunicação virtual entre ONGs e } \\
\text { construção do conhecimento - o } \\
\text { caso da rede ANDI Brasil }\end{array}$ \\
\hline Lima & 2005 & UnB & Comunicação & M & $\begin{array}{l}\text { Impacto da agenda social no } \\
\text { jornalismo brasileiro - Agência de } \\
\text { Notícias dos Direitos da Infância: } \\
\text { uma experiência exemplar de } \\
\text { Jornalismo Público }\end{array}$ \\
\hline F. Pereira & 2005 & USP & Comunicação & M & $\begin{array}{l}\text { Em nome da criança e do } \\
\text { adolescente: ONGs e imprensa em } \\
\text { parceria na construção do noticiário }\end{array}$ \\
\hline Ribeiro & 2005 & UNESP & Comunicação & $M$ & $\begin{array}{l}\text { Jornalismo regional e construção da } \\
\text { cidadania: o caso da Folha da Região } \\
\text { de Araçatuba }\end{array}$ \\
\hline Bonfim & 2005 & UnB & Comunicação & $M$ & $\begin{array}{l}\text { O papel das fontes na construção da } \\
\text { notícia o agendamento do tema } \\
\text { trabalho infantil doméstico no } \\
\text { jornalismo impresso brasileiro, no } \\
\text { ano de } 2003\end{array}$ \\
\hline Brasiliense & 2006 & UFF & Comunicação & M & $\begin{array}{l}\text { Tessituras narrativas de o globo e o } \\
\text { acontecimento "chacina da } \\
\text { Candelária" }\end{array}$ \\
\hline Nunes & 2007 & USM & Comunicação & $\bar{M}$ & $\begin{array}{l}\text { A criança e o adolescente na } \\
\text { imprensa paulista (Jornal: Folha de } \\
\text { São Paulo-1990/2000) }\end{array}$ \\
\hline J. Silva & 2007 & UFPE & Comunicação & M & Violência sexual doméstica contra \\
\hline
\end{tabular}




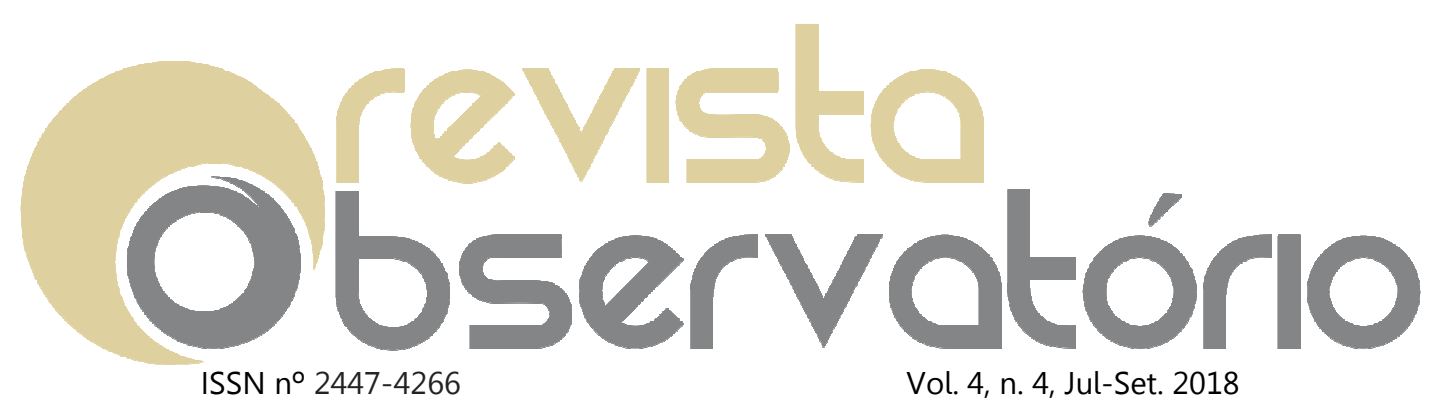

DOI: https://doi.org/10.20873/uft.2447-4266.2018v4n4p571

\begin{tabular}{|c|c|c|c|c|c|}
\hline & & & & & crianças e adolescentes na imprensa \\
\hline Kraemer & 2008 & PUCRS & $\begin{array}{l}\text { Ciências } \\
\text { Sociais }\end{array}$ & M & $\begin{array}{l}\text { Entre o público e o privado: } \\
\text { Interpretações sobre estórias de } \\
\text { abuso sexual em narrativas } \\
\text { jornalísticas }\end{array}$ \\
\hline Farah & 2008 & UTP & Comunicação & M & $\begin{array}{l}\text { Representações Visuais da Criança } \\
\text { na Imprensa: uma análise dos jornais } \\
\text { Folha de S. Paulo e O Estado de S. } \\
\text { Paulo }\end{array}$ \\
\hline Mora & 2008 & UnB & Comunicação & $M$ & $\begin{array}{l}\text { O Concurso Tim Lopes de } \\
\text { Investigação Jornalística como } \\
\text { estratégia de agendamento da } \\
\text { violência sexual contra crianças e } \\
\text { adolescentes na imprensa brasileira }\end{array}$ \\
\hline Oliveira & 2008 & UnB & Comunicação & M & $\begin{array}{l}\text { Jornalismo para além do valor- } \\
\text { notícia. O valor-convergente como } \\
\text { modelo para selecionar e inserir } \\
\text { temas sociais na mídia }\end{array}$ \\
\hline Dias & 2008 & UnB & Comunicação & M & $\begin{array}{l}\text { A influência do prêmio Jornalista } \\
\text { Amigo da Criança sobre o } \\
\text { profissional de jornalismo: um } \\
\text { estudo de caso }\end{array}$ \\
\hline Santos & 2008 & UFPE & Comunicação & M & $\begin{array}{l}\text { O agendamento do jornalismo: um } \\
\text { estudo de caso sobre a infância e } \\
\text { adolescência em Pernambuco }\end{array}$ \\
\hline Pistolato & 2008 & UNIMAR & Comunicação & M & $\begin{array}{l}\text { A influência da comunicação na } \\
\text { erradicação das piores formas de } \\
\text { trabalho infantil no Paraná: } \\
\text { Programa Catavento }\end{array}$ \\
\hline Campos & 2008 & UFMG & $\begin{array}{l}\text { Ciências da } \\
\text { Saúde }\end{array}$ & M & $\begin{array}{l}\text { A infância sem segredos: a } \\
\text { noticiabilidade jornalistica do crime } \\
\text { de exploração sexual de crianças e } \\
\text { adolescentes }\end{array}$ \\
\hline Bizzo & 2008 & PUCSP & Psicologia & M & $\begin{array}{l}\text { Infância associada ao tema aborto } \\
\text { voluntário em peças jornalísticas } \\
\text { publicadas pelo jornal online da } \\
\text { Folha de S. Paulo (1997-2005) }\end{array}$ \\
\hline
\end{tabular}




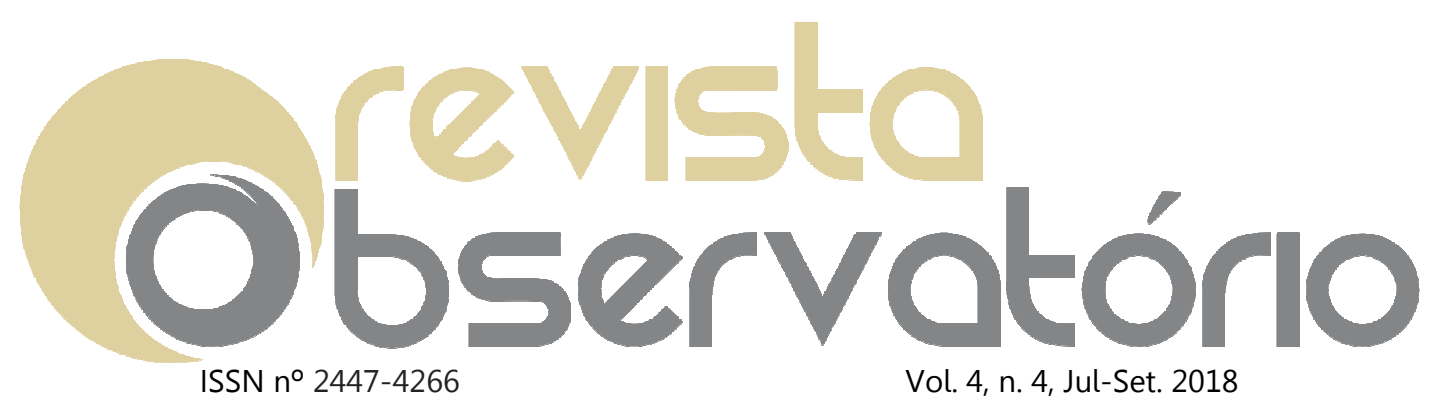

DOI: https://doi.org/10.20873/uft.2447-4266.2018v4n4p571

\begin{tabular}{|l|l|l|l|l|l|}
\hline Anselmo & 2009 & UFRGS & Comunicação & M & $\begin{array}{l}\text { A representação das práticas } \\
\text { socioculturais de crianças e } \\
\text { adolescentes do jornal boca de rua: a } \\
\text { experiência do boquinha }\end{array}$ \\
\hline Reimberg & 2009 & USP & Comunicação & M & $\begin{array}{l}\text { Comunicação, educação e saúde: a } \\
\text { ação da Pastoral da Criança para a } \\
\text { cidadania na Arquidiocese de São } \\
\text { Paulo }\end{array}$ \\
\hline Cerqueira & 2009 & PUCRIO & Comunicação & M & $\begin{array}{l}\text { Jornalismo e exclusão social - Análise } \\
\text { comparativa nas coberturas sobre } \\
\text { crianças e adolescentes }\end{array}$ \\
\hline
\end{tabular}

Fonte: elaborado pelos autores

O não escopo seria caracterizado por: desdobramentos das teses e dissertações em artigos de revistas e em congressos. Também não leva em conta: grupos de pesquisa, linhas de pesquisa, áreas de concentração, livros, monografias, trabalhos de mestrado profissional em Jornalismo (no Brasil: UFPB, FIAM-FAAM, ESPM). Mas também, tematicamente caracterizado por trabalhos orientados para o polo do receptor ${ }^{11}$.

Esse esclarecimento é necessário devido ao fato de que: as palavraschave capturam trabalhos que podem ter temas afins, mas não são objetos com o esforço e foco de estudo nos termos em apreço deste artigo. Logo, foram localizados, mas excluem-se da massa analítica: os trabalhos abaixo (justificativa na coluna da extrema direita).

\footnotetext{
${ }^{11}$ Inclusos: abordagens da mensagem, de código e de canal que apontem para o polo do receptor.
} 


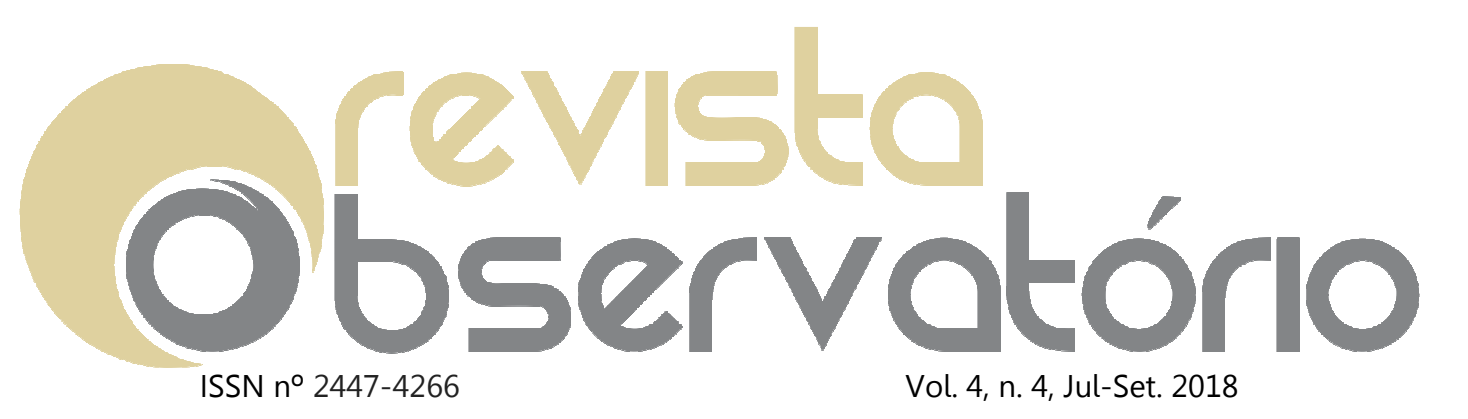

DOI: https://doi.org/10.20873/uft.2447-4266.2018v4n4p571

Quadro 8 - Teses e dissertações sobre criança e adolescente que apontam para o polo do receptor e outras possibilidades fora do escopo

\begin{tabular}{|c|c|c|c|}
\hline Autor & Ano & Título & Abordagens fora do escopo \\
\hline M. Costa & 1992 & $\begin{array}{l}\text { Ler sem engasgar: dois tipos de recepção } \\
\text { do jornalismo infantil da Folhinha - } \\
\text { suplemento infantil da Folha de S. Paulo }\end{array}$ & $\begin{array}{l}\text { Estuda como as crianças leem o } \\
\text { jornal. }\end{array}$ \\
\hline Moura & 1997 & $\begin{array}{l}\text { As meninas do mangue: uma psicologia } \\
\text { da memória }\end{array}$ & $\begin{array}{l}\text { Como indivíduo recorre a } \\
\text { memórias da infância }\end{array}$ \\
\hline $\begin{array}{l}\text { Girardell } \\
\mathrm{O}\end{array}$ & 1998 & $\begin{array}{l}\text { Televisão e imaginação infantil: Histórias } \\
\text { da Costa da Lagoa }\end{array}$ & $\begin{array}{l}\text { Imaginação infantil depois de } \\
\text { estimuladas pela TV }\end{array}$ \\
\hline Sampaio & 1999 & $\begin{array}{l}\text { A tematização da infância nas esferas } \\
\text { públicas mediáticas: uma análise centrada } \\
\text { na propaganda de televisão }\end{array}$ & $\begin{array}{l}\text { Tematização em publicidade e } \\
\text { propaganda }\end{array}$ \\
\hline $\begin{array}{c}\text { M. } \\
\text { Pereira }\end{array}$ & 2001 & $\begin{array}{l}\text { Representação social de pais e crianças } \\
\text { com meningite bacteriana }\end{array}$ & $\begin{array}{l}\text { Como pais entendem os } \\
\text { diagnósticos de seus filhos } \\
\text { dados por médicos }\end{array}$ \\
\hline Mendes & 2002 & O jornal infantil interativo & $\begin{array}{l}\text { Estudo de recepção que checa } \\
\text { as necessidades do público } \\
\text { infantil em suplementos }\end{array}$ \\
\hline Melo & 2003 & $\begin{array}{l}\text { Olho na tela e pé no chão - Informação } \\
\text { sobre meio ambiente, criança e internet }\end{array}$ & $\begin{array}{lr}\text { Como a mídia pode } & \text { criar } \\
\text { consciência ambiental } & \text { no } \\
\text { público infantil } & \end{array}$ \\
\hline Escovar & 2005 & $\begin{array}{l}\text { O Tema sexo na revista Todateen: um } \\
\text { estudo freudiano }\end{array}$ & $\begin{array}{l}\text { Como o indivíduo lê o jornal } \\
\text { juvenil, a partir da psicanálise. }\end{array}$ \\
\hline Ruiz & 2005 & $\begin{array}{l}\text { Gestão da informação: da criação à } \\
\text { recepção. Estudo de caso: Revista } \\
\text { Todateen - para público adolescente }\end{array}$ & $\begin{array}{l}\text { Todo o ciclo de processamento } \\
\text { da informação até chegar à } \\
\text { recepção. }\end{array}$ \\
\hline Carvalho & 2009 & $\begin{array}{l}\text { A iconografia da AIDS: um estudo } \\
\text { comparativo da comunicação impressa na } \\
\text { prevenção à AIDS para o público } \\
\text { adolescente no período de } 1993 \text { a } 2007\end{array}$ & $\begin{array}{l}\text { Como a propaganda de saúde é } \\
\text { percebida pela recepção: } \\
\text { adolescentes }\end{array}$ \\
\hline Prado & 2009 & $\begin{array}{l}\text { A criança, o jovem e sua permanente } \\
\text { busca de identidades em tempos de } \\
\text { novos meios e Pós-Modernidade }\end{array}$ & $\begin{array}{l}\text { Formação de identidade no } \\
\text { público leitor infanto-juvenil }\end{array}$ \\
\hline
\end{tabular}

Fonte: elaborado pelos autores 


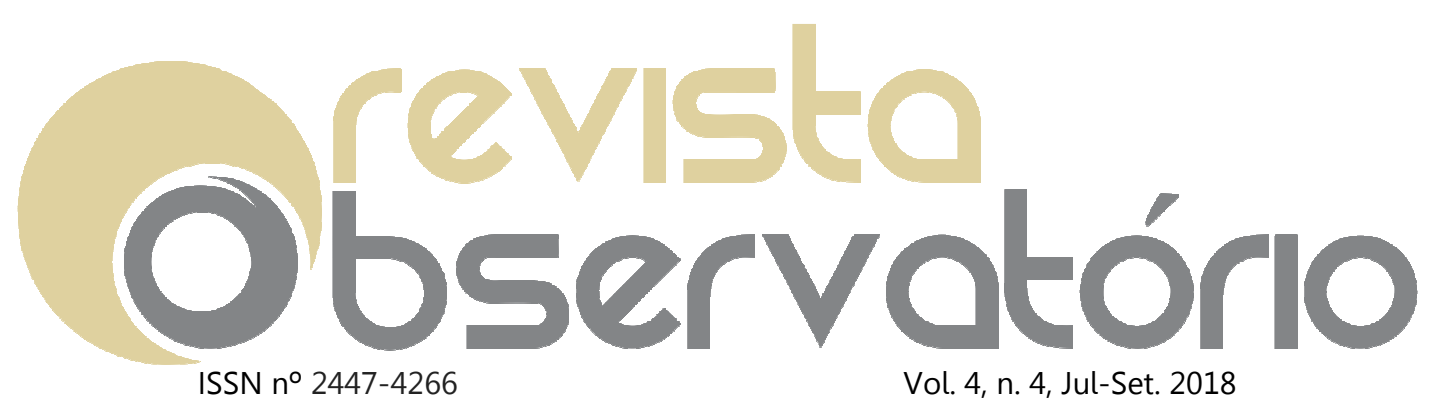

DOI: https://doi.org/10.20873/uft.2447-4266.2018v4n4p571

\section{Anos 1990 - um tema perpassado por várias áreas}

O primeiro registro sobre o estudo da criança e do adolescente em termos de processamento pelo jornalismo e pela comunicação é Bastos (1995): O movimento de defesa da criança e do adolescente: uma contribuição para sua análise, dissertação em Educação, Universidade Federal Fluminense (UFF), por meio de análise de conteúdo de noticiário na imprensa impressa da cidade do Rio de Janeiro, desenvolve o cenário brasileiro pós-Estatuto da Criança e do Adolescente (ECA), inserido na doutrina de proteção integral que emana desta legislação, com a discussão sobre a defesa da infância e da adolescência no Brasil. O foco destes primeiros trabalhos está nos marcos legais.

A. Costa (1996), O pão do corpo o pão da inteligência e o pão do coração - o lugar da criança na sociedade 1927-1990, dissertação em História, Pontifícia Universidade Católica de São Paulo (PUCSP), trata da sequência histórica da edição do Código de Menores ${ }^{12}$ (1927; 1979) e o marco da doutrina de proteção integral (1990) as categorias de abandono e delinquência da criança e do adolescente no meio urbano, a partir da legislação e enfoques no noticiário. No mesmo ano, Santos (1996) desenvolve o estudo Meninas, sexo e espaço público: análise do discurso jornalístico cearense sobre a prostituição infantil, dissertação em Sociologia, Universidade Federal do Ceará (UFC), a partir de um corpus de 39 matérias de O Povo, Diário do Nordeste e Tribuna do Ceará, tratando da prostituição infantil ${ }^{13}$ onde a autora investigava a

\footnotetext{
${ }^{12}$ A expressão menor, atualmente, é designada por: crianças em conflito com a lei.

${ }^{13}$ A expressão prostituição infantil, atualmente, é designada por: exploração sexual e comercial de crianças e adolescente; ou crianças e adolescentes em situação de risco, onde o risco é a perda de algum direito fundamental dessa categoria.
} 


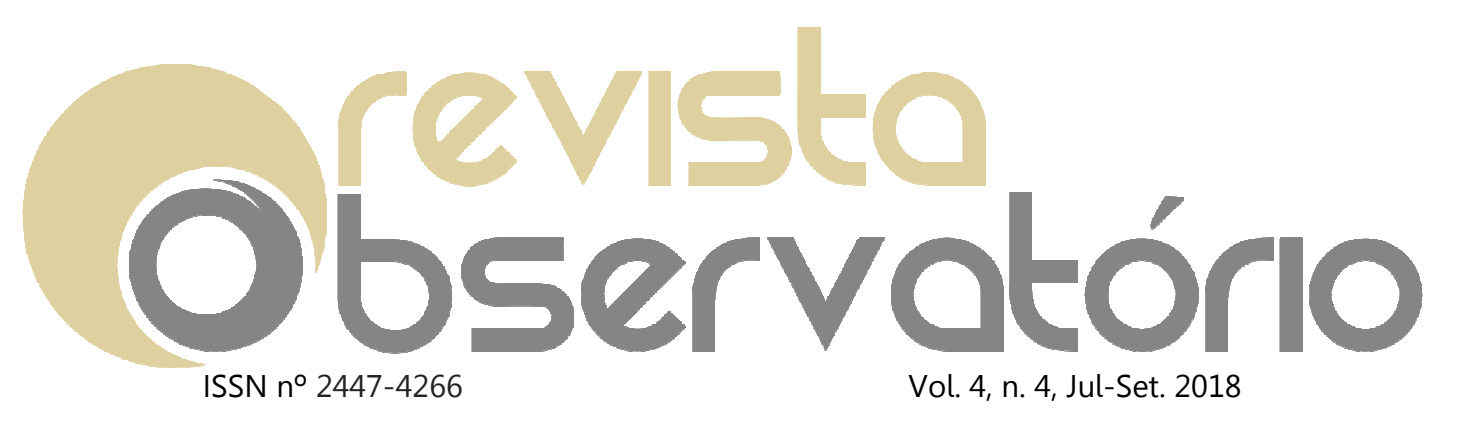

DOI: https://doi.org/10.20873/uft.2447-4266.2018v4n4p571

discursividade entre as categorias: infantil e o erótico. Também do nordeste, no mesmo ano, Figueiredo (1996), em Informação e cidadania: meninos de rua no discurso da imprensa paraibana, com a primeira dissertação sobre o tema em Biblioteconomia, Universidade Federal da Paraíba (UFPB), na qual, pelo viés da Ciência da Informação, e da análise de discurso, a autora utilizava a categoria meninos de rua ${ }^{14}$, a partir do corpus dos jornais: $O$ Norte, Correio da Paraíba e A União (1988-1993), identificando esta pauta com inserção contumaz nas editorias de segurança e de ações policiais.

No ano seguinte, Frontana (1997), Cotidiano de crianças e adolescentes nas ruas da metrópole paulistana: sob o fogo cruzado de posturas e opiniões (1964-1965), dissertação em História Social, pela Universidade de São Paulo (USP), trabalhou com a categoria menor de idade e suas relações com Estado e Sociedade, durante o Regime Militar, a partir da imprensa paulista. Em seguida, Trindade (1998) inaugura a os estudos em nível de doutorado, com a tese Metamorfose de criança para menor: Curitiba início do século XX, da História, Universidade Federal do Paraná (UFPR), que utilizou análise do discurso fazendo uma revisão historiográfica de 280 processos do Juizado de Menores (Curitiba); além de material publicado no jornal $A$ República (entre 1890-1906) e do Diário da Tarde (1920-1930). Fechando os anos 1990, J. Souza (1999), Da infância desvalida à infância delinquente: Fortaleza (1865-1928), dissertação em História (PUCSP), trabalha em relação ao abandono e delinquência.

Até então, os trabalhos versavam sobre material empírico gerado pelos registros de matérias jornalísticas buscando representações sociais da infância e da adolescência. Mas não havia uma preocupação em tratar da pauta em si (mas sim da representação social e historicidade no noticiário). No entanto, M.

\footnotetext{
${ }^{14}$ A expressão meninos de rua, atualmente, é designada por: meninos em situação de rua.
} 


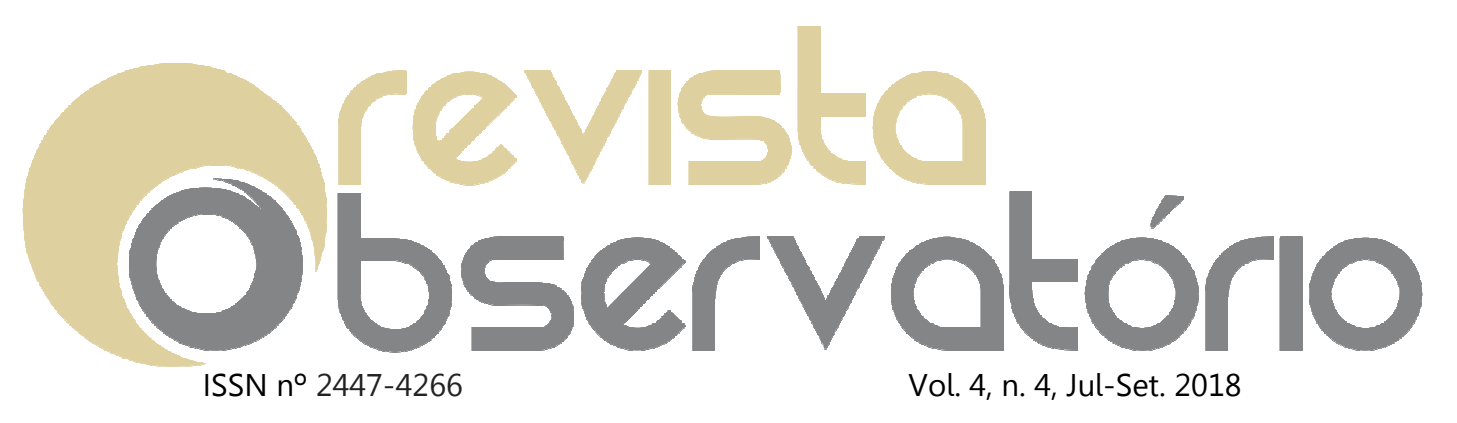

DOI: https://doi.org/10.20873/uft.2447-4266.2018v4n4p571

Souza (1999), em Infância de papel: análise do discurso jornalístico sobre a infância na imprensa brasileira, estabelece um marco com a primeira dissertação em Comunicação sobre o assunto, Universidade Federal do Rio de Janeiro (UFRJ). E também pela ruptura o tipo de abordagem: os trabalhos anteriores tinham aparato teórico-metodológico baseado em análise do discurso e análise de conteúdo, mas a autora lança mão de recursos da análise semiológica para trabalhar material empírico baseado em revistas (e não somente em jornais: outra mudança) e o discurso da mídia impressa sobre a infância. É a primeira pesquisa a trabalhar, exclusivamente, com a questão da pauta como parte integrante do relato jornalístico, a partir da tematização do noticiário e suas funções: Informativa, Denuncista e Didática (SOUZA, 1999, p. 107). Um dos focos deste artigo ${ }^{15}$.

Institucionalizado o estudo da pauta jornalística, em M. Souza (1999), percebe-se que as pesquisas em Comunicação passam a explorar mais o tema e problematizá-lo em diversas configurações de objeto de estudo.

\section{Anos 2000 - o tema na área da Comunicação}

M. Pereira (2000), dissertação em Comunicação, Universidade de Brasília (UnB), Condenados à Juventude: Um estudo comparativo sobre a juvenilização no jornalismo brasileiro, trata da questão da produção midiática e como ela enquadra os jovens em diferentes períodos da história, ao utilizar as categorias: criança, adolescente, adulto e velho. É o primeiro trabalho da região Centro-

\footnotetext{
${ }^{15}$ M. Costa (1992), sob orientação de Lúcia Santaella, também utilizou abordagem semiótica, mas trabalhava com aspectos da recepção, um foco que não nos interessa no escopo de análise. Mendes (2002) também trata da pauta jornalística, O jornal infantil interativo, mas checando a melhor configuração de jornal para público infantil (recepção).
} 


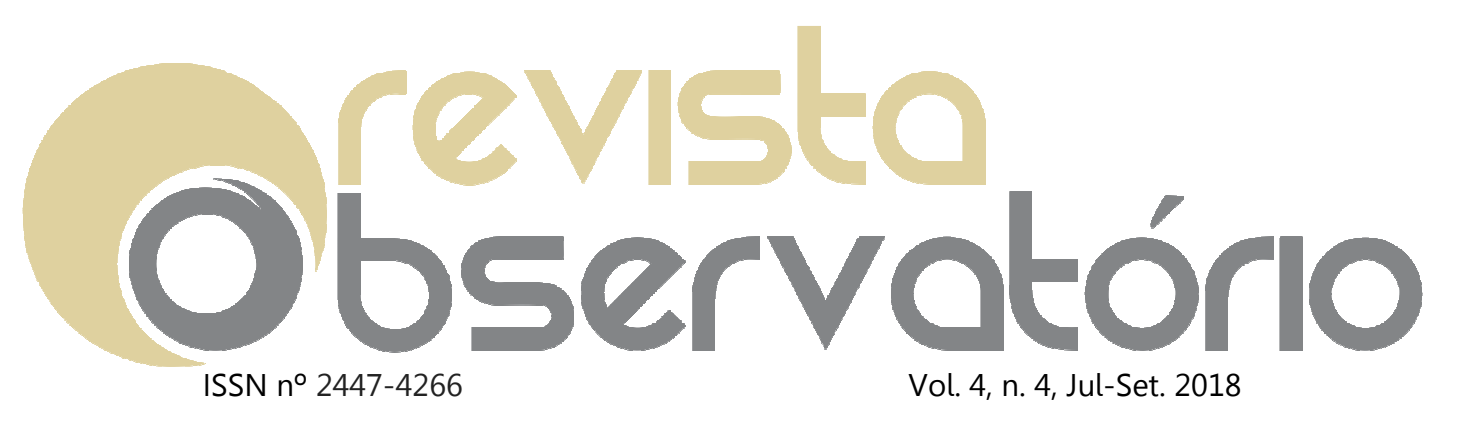

DOI: https://doi.org/10.20873/uft.2447-4266.2018v4n4p571

Oeste. Mattos (2000), dissertação em Comunicação, UFRJ, estuda como as implicações socioculturais na constituição de sua identidade refletem no surgimento de trabalhos alternativos, comunitários, junto a jovens pertencentes às classes sociais desfavorecidas. E neste contexto aborda a questão da formação do jovem pela mídia e meios de comunicação: um trabalho que protagoniza Terceiro Setor, a infância e adolescência em relação ao ambiente da Comunicação. Na sequência, começam a ser editadas pesquisas sobre cidadania e a figura da criança. Faraone (2001), dissertação em Comunicação (USP), Temas de cidadania em jornais infantis - um estudo dos suplementos $A$ Gazetinha, Diário Criança, Estadinho e Folhinha é um bom exemplo.

Na primeira metade dos anos 2000, a Psicologia Social passaria a atuar intensivamente na produção de conhecimento sobre o tema (investigações, em sua maioria sobre representações sociais), tradição que foi da História nos anos 1990: 50\% da produção daquele período (investigações sobre memória e historicidade). $O$ protagonismo da PUCSP pelo PPG de História ${ }^{16}$, nos anos 1990, passaria para o PPG da Psicologia Social, nos anos 2000, baseados na atuação do Núcleo de Estudos de Gênero, Raça e Idade (NEGRI): Andrade (2001), Freitas (2004), Nazareth (2004), Andrade (2005) e Bizzo (2008).

Andrade (2001), uma tese: Prostituição infanto-juvenil e mídia: estigmatização da pobreza e ideologia (PUCSP), verificava a construção social da infância e adolescência no Brasil, utilizando-se do tratamento dado pela mídia ao tema da prostituição infanto-juvenil no Brasil, por meio da

\footnotetext{
${ }^{16}$ Dos 8 estudos sobre o tema em apreço, na década de 1990 (UFF, UFC, UFPB, USP, UFPR, UFRJ), a PUCSP acumula 25\% dos esforços, a contar pelas dissertações de J. Souza (1999) e M. Costa (1996): ambas do PPG de História. Sendo a UFPR, a primeira a produzir uma tese sobre o assunto, também pela História, naquele período.
} 


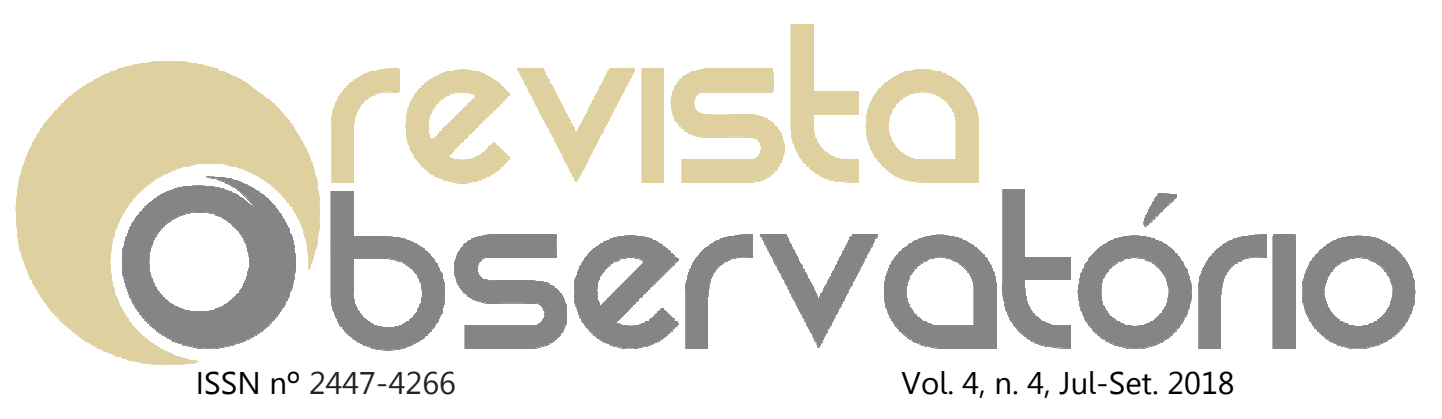

DOI: https://doi.org/10.20873/uft.2447-4266.2018v4n4p571

hermenêutica de profundidade e de análise de conteúdo, tendo como corpus o noticiário da Folha de S. Paulo (1985-1995).

Jacob (2002), Infância na arena das palavras: as relações discursivas sobre a criança de rua no jornal impresso, dissertação em Comunicação (USP), estuda o noticiário a partir de análise do discurso no noticiário impresso da Folha de $\mathrm{S}$. Paulo e do O Estado de S. Paulo. Guarnieri (2002), dissertação também em Comunicação e pela USP, Violência e imprensa. O tratamento mediático da violência criminal juvenil, tem o mesmo perfil de investigação.

No mesmo ano, Rebechi (2002) olha não somente para o jornalismo e veículos tradicionais, mas para as ONG's que agenciam direitos da criança e do adolescente ${ }^{17}$ : Agência de Notícias dos Direitos da Infância ANDI - Um Estudo Preliminar de uma Organização do Terceiro Setor, dissertação em História, pelo Mackenzie. Este estudo é muito importante e inovador, pois ele, por mais que seja da História, dá bases para o estudo da ANDI, que é uma das responsáveis pela mudança de discurso, ideologia e tratamento desta pauta no noticiário brasileiro $^{18}$, como veremos em pesquisas mais à frente. Neste sentido, podemos dizer que Rebechi (2002) inaugura o estudo da pauta em organizações nãojornalísticas ${ }^{19}$, no sentido formal e empresarial do mercado noticioso, pois a ANDI é um ONG (recursos privados para fins públicos: Terceiro Setor); e não

\footnotetext{
${ }^{17}$ Reforçando olhar para o Terceiro Setor, visto em Mattos (2000).

${ }^{18}$ Inclusive na produção de cartilhas de orientação aos jornalistas para abdicar a certo rol de palavras (prostituição infantil, menor), em prol de outras (criança em situação de risco, criança em conflito com a lei): como visto em notas anteriores. O que configura lutas ideológicas e o transitar de consciências a partir da linguagem e do discurso jornalístico sobre a pauta da criança.

${ }^{19}$ Mattos (2000) aborda o Terceiro Setor e a codificação de mensagens pelo emissor, mas não de modo exclusivo e ostensivo, como Rebechi (2002). Há uma reorientação dos interesses de pesquisa ao se abrir o leque de opções de estudo em empresa jornalísticas (redações tradicionais comerciais) e, também: não-jornalísticas (ONGs e mecanismos de ativismo executivo de acesso ao Espaço Público, Espaço Midiático e Agenda Pública).
} 


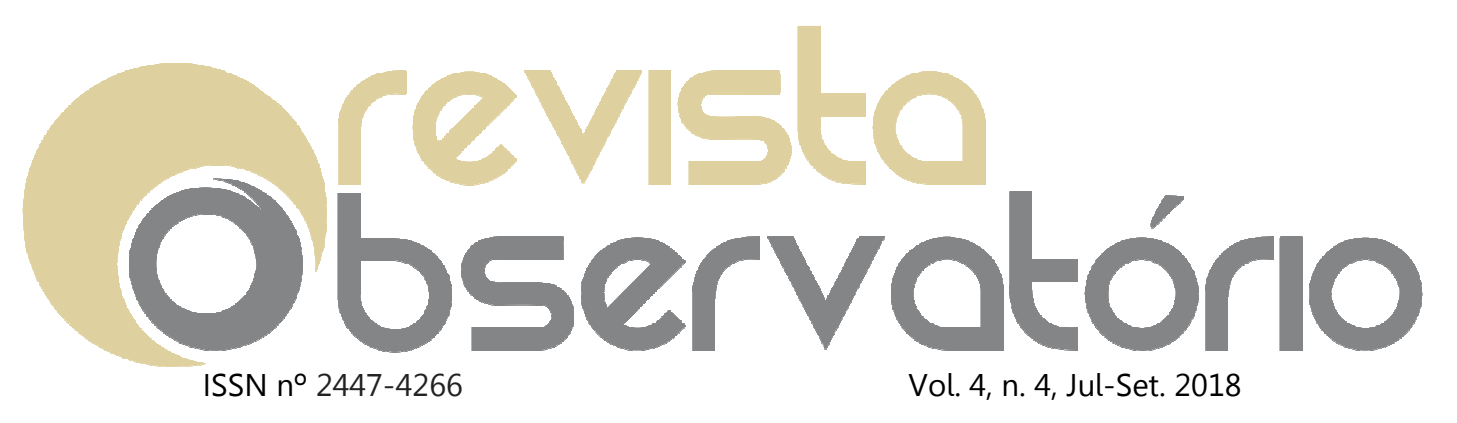

DOI: https://doi.org/10.20873/uft.2447-4266.2018v4n4p571

uma empresa jornalística (recursos privados para fins privados: Mercado). Esta singularidade vai ser o mote da virada nos estudos: a partir da segunda metade dos anos 2000, como veremos na próxima seção.

Voltando à sequência, eis que surge a primeira tese em Comunicação: Duarte (2003), Cidadania obstruída: jornais cariocas e a construção discursiva da violência no Rio (UFRJ), que trabalhou com a categoria violência urbana no noticiário policial (2000-2002) relativa à criança e ao adolescente, por meio da Semiologia e do conceito de Hegemonia ${ }^{20}$. A partir deste momento, na Comunicação, já entram em cena nas abordagens os aspectos relativos à Teoria da Notícia, como: seleção das notícias, processo de produção da notícia. Um exemplo é Azevedo (2003), em Trabalho infantil, movimentos sociais e imprensa: um olhar sobre o fazer jornalístico, dissertação em Comunicação (USP). A autora já em seu título faz a marcação da Teoria da Notícia a partir do estudo da categoria trabalho infantil processada como notícia na Fábrica de Notícias (Newsmaking). Azevedo (2003) utilizou diversas entrevistas com agentes sociais e com jornalistas especializados. Trata-se do primeiro estudo com o viés etnográfico de Newsmaking com metodologia de verificação em campo, para muito além das técnicas de pesquisa utilizadas até então: análise de conteúdo e análise de discurso frente a um corpus de notícias ${ }^{21}$. Também faz a demarcação de uma nova cosmovisão dos estudos, pois começam a aparecer

\footnotetext{
${ }^{20}$ Muito importante para os estudos de Jornalismo dessa época com o uso da noção de $A$ ção Comunicativa (Habermas) vinculada à Teoria da Notícia no que se convencionou chamar de Contra-Agendamento, por alguns.

${ }^{21}$ Ressaltamos que estudar a notícia circulante (as publicações em si: o produto jornalístico) não é a mesma coisa que estudar a pauta jornalística e suas especificidades (institucionalização de um discurso a partir do processo de produção da notícia: o processo jornalístico).
} 


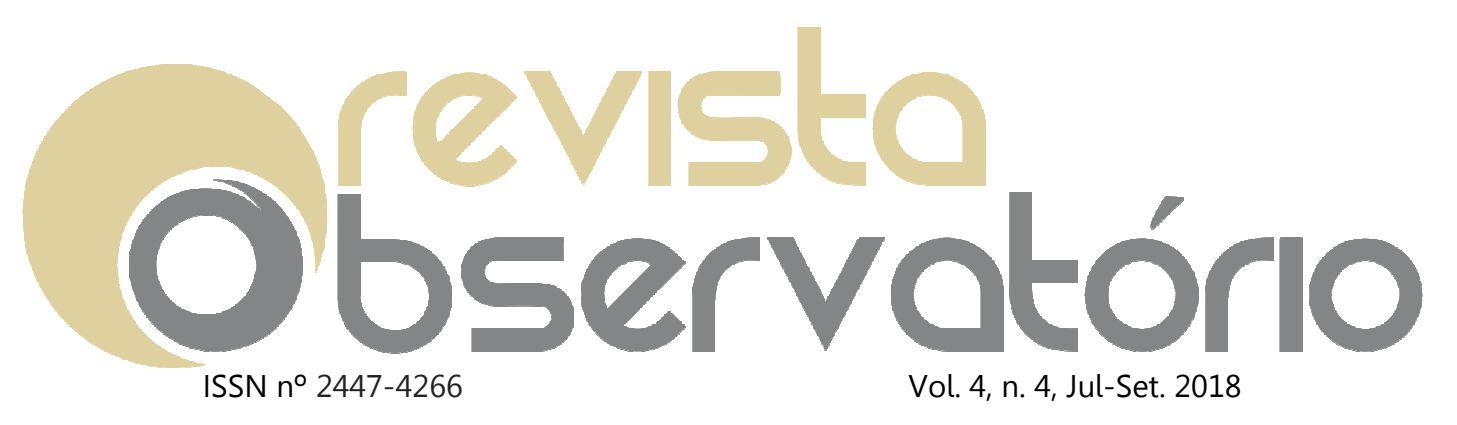

DOI: https://doi.org/10.20873/uft.2447-4266.2018v4n4p571

elementos com uma visão positiva do tratamento da pauta da criança e do adolescente no noticiário ${ }^{22}$.

A Psicologia Social, da PUCSP, contribui com mais 3 trabalhos: Freitas (2004), em O tema trabalho infanto-juvenil na mídia: uma interpretação ideológica, segunda tese em Psicologia Social (PUCSP), trabalha a tematização do trabalho infanto-juvenil a partir de amostra documental da Folha de S.Paulo (1980-2001), por meio da hermenêutica de profundidade, análise de conteúdo e da Sociologia da Infância. Neste mesmo ano, Nazareth (2004) é a primeira a abordar exclusivamente a categoria do adolescente (além do gênero feminino): na dissertação $O$ discurso da mídia sobre a adolescente grávida: uma análise da ideologia. Ainda há o trabalho de Andrade (2005) em A categoria "meninos de rua" na mídia: uma interpretação ideológica, terceira tese em Psicologia Social (PUCSP), com estudo sobre a Folha de S. Paulo na categoria meninos de rua (1980-2001).

A área de Educação contribui com duas teses: Assis (2004), Psicologia, educação e reforma dos costumes: lições da Selecta Cathólica (1846-1847), Universidade Federal de Minas Gerais (UFMG)(1); e Andreotti (2004), A formação de uma geração: a educação para a promoção social e o progresso do país no jornal a voz da infância da biblioteca infantil municipal de São Paulo (19361950), Universidade Estadual de Campinas (Unicamp). Assis (2004) tem uma abordagem interessante (historiografia) por ser de um jornal organizacional no século XIX, onde verifica a proposta educativa de D. Antônio Ferreira Viçoso, bispo de Mariana, que pelo jornal religioso Selecta Catholica circulava um discurso de catequese com delineamentos bem específicos sobre a criança e a

\footnotetext{
${ }^{22}$ Diferentemente do que vimos nas pesquisas históricas produzidas nos anos 1990, pela Educação, História, Sociologia, Biblioteconomia.
} 


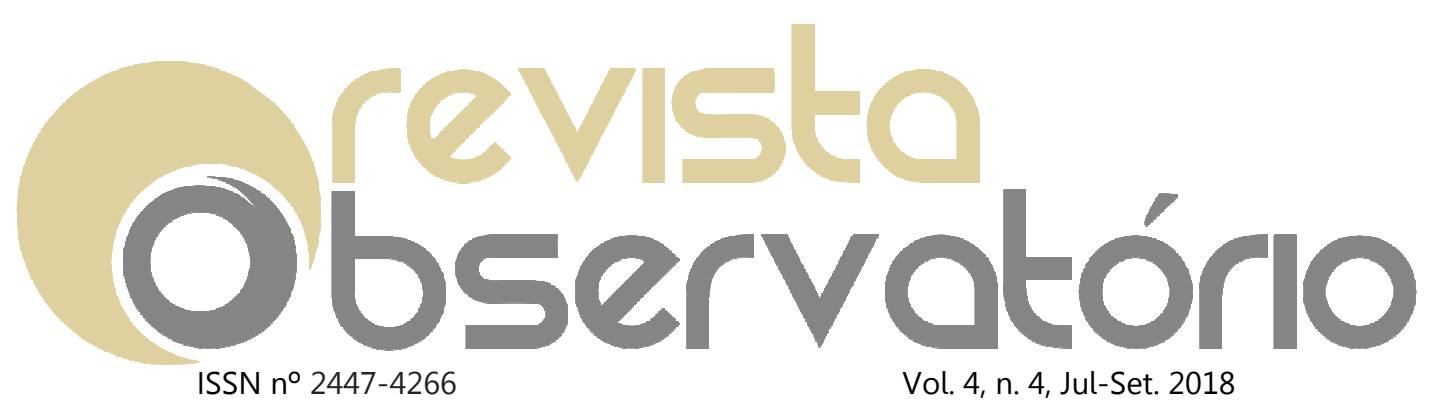

DOI: https://doi.org/10.20873/uft.2447-4266.2018v4n4p571

família, com o início da ideia de infância e adolescência com o desenvolvimento dos centros urbanos, saneamento básico, medicina e legislação, no século XIX e XX (M. SOUZA, 1999). Andreotti (2004) também versa sobre publicação organizacional.

\section{A virada nas abordagens em favor da Teoria da Notícia}

Um efeito de Rebechi (2002), no estudo de organizações não-jornalísticas (ONG's como a ANDI), para muito além dos veículos jornalísticos tradicionais, é o que chamamos de virada no perfil dos estudos. Os pesquisadores percebem um ambiente de advocacy e de uma nova concepção de pauta da criança e do adolescente, signatária da doutrina da proteção integral (ECA/1990).

Raposo (2005), na dissertação: Comunicação virtual entre ONGs e construção do conhecimento - o caso da rede ANDI Brasil, Universidade Federal do Pernambuco (UFPE) mostra essa guinada: o noticiário passa a não ser entendido mais somente como sendo feito por veículos jornalísticos tradicionais (jornais e revistas). As agências de notícias do Terceiro Setor são incluídas nesse rol. A mais proeminente dessas ONG's é a ANDI, mas outros estudos até o fim da década tratariam da Central de Notícias dos Direitos da Infância e Adolescência (Ciranda), Catavento Comunicação e Educação ${ }^{23}$. É uma mudança de paradigma: com foco na produção da notícia e agendamento da pauta da criança e do adolescente para muito além do "mercado" noticioso ou

\footnotetext{
${ }^{23}$ Outras, mas sem estudos específicos: Notícias da Infância Matraca (Maranhão), Central CIPÓ de Notícias - CCN (Bahia), Auçuba - Comunicação e Educação (Pernambuco), Catavento Comunicação e Educação (Ceará), Gira Solidário - Agência de Notícias em Defesa da Infância (Mato Grosso do Sul), Instituto Recriando (Sergipe) e Oficina de Imagens - Comunicação e Educação (Minas Gerais). O escritório da ANDI é em Brasília (Distrito Federal) e da Ciranda em Curitiba (Paraná). A ANDI chamava-se Agência de Notícias dos Direitos da Criança (1993-2012) e, hoje, se chama ANDI Comunicação e Direitos.
} 


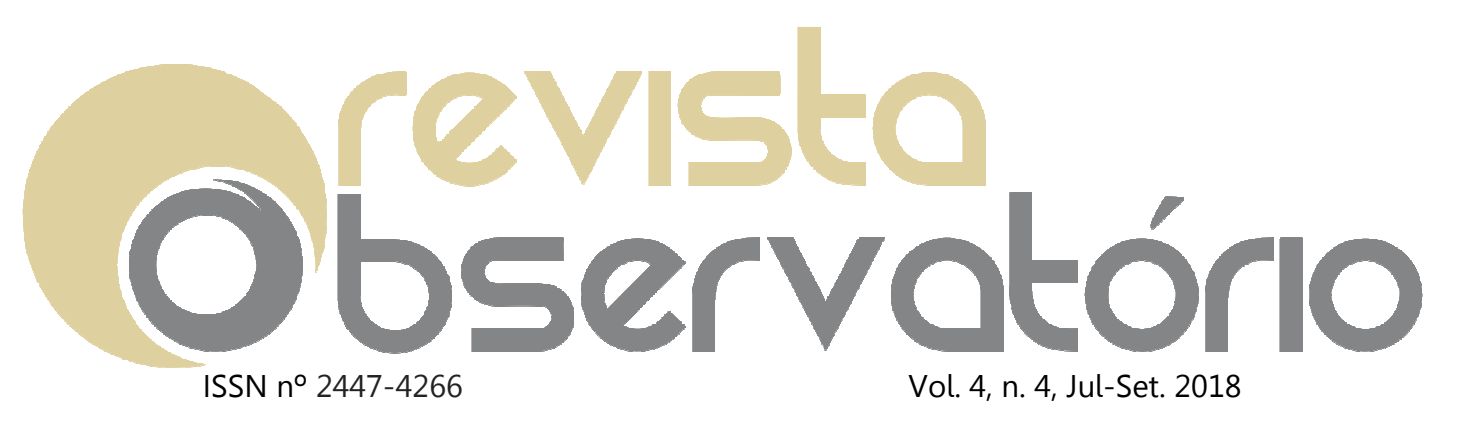

DOI: https://doi.org/10.20873/uft.2447-4266.2018v4n4p571

veículos empresariais. Essa noção é ampliada para uma Agenda que visa: acesso ao Espaço Público e ao Espaço Midiático.

\section{5 - a troca de eixo: do Segundo Setor (mercado) para o Terceiro Setor}

Se o protagonismo do NEGRI/PUCSP, na Psicologia Social, como núcleo, foi essencial para os estudos da criança e do adolescente no noticiário (com edição de 3 teses), a partir de 2005, entra em cena a atuação da UnB, por meio dos projetos de pesquisa: Como o Terceiro Setor pauta a mídia (2003-2006) e $O$ Jornalismo como Teoria Democrática (2006-2009), que tiram o foco da notícia como sendo apenas de um mercado noticioso (Segundo Setor) e o passam para a Sociedade Civil (Terceiro Setor).

Para muito além do jornalismo em veículos tradicionais, conforme visto em Rebechi (2002) e Raposo (2005), Lima (2005) em Impacto da agenda social no jornalismo brasileiro - Agência de Notícias dos Direitos da Infância: uma experiência exemplar de Jornalismo Público, dissertação em Comunicação (UnB), traz já no título o pioneirismo e força da ANDI na pauta da criança e do adolescente, nos anos 2000: "experiência exemplar em Jornalismo" (LIMA, 2005, p.1). E também se percebe a diferença do perfil destas pesquisas em relação às dos anos 1990, que ainda lamentavam o noticiário da infância e da adolescência e tinham visões muito negativas sobre as práticas jornalísticas e midiáticas. Neste trabalho, a autora foca na agenda social e em estruturas como o Agendamento e Contra-Agendamento (L. SILVA, 2007), enfatizando o ativismo crescente do Terceiro Setor e instrumentalização por meio do Jornalismo Público. A abordagem trabalha a mudança na cultura profissional dos jornalistas brasileiros a partir de 


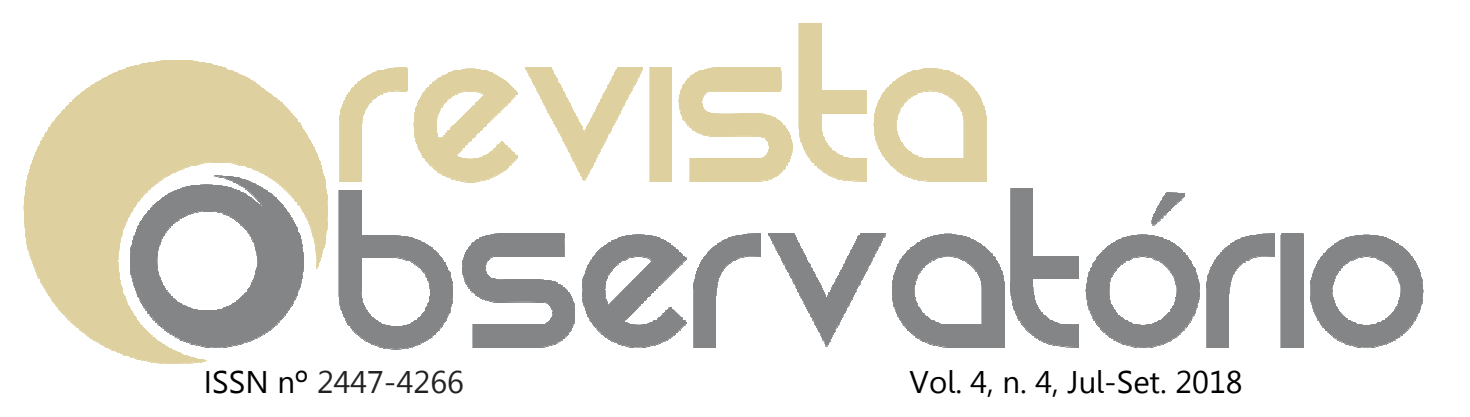

DOI: https://doi.org/10.20873/uft.2447-4266.2018v4n4p571

uma importante interface entre o espaço social e o mercado da mídia. Suas estratégias, além de múltiplas e consolidadas, são exemplares e replicáveis. O jornalismo vem se renovando, cada vez mais sintonizado com este setor. Dezenas de jornalistas questionados para este trabalho confirmam a tendência e desvendam sua visão pessoal da inata - função social da mídia. Identificam gargalos e apontam caminhos de aproximação que qualifiquem a atividade jornalística e reforcem o seu papel na sociedade. É o despontar do chamado "jornalismo público", cívico, engajado (LIMA, 2005, p. 5).

F. Pereira (2005), Em nome da criança e do adolescente: ONGs e imprensa em parceria na construção do noticiário, dissertação em Comunicação (USP), tem foco no Terceiro Setor e no agenciamento da cidadania por ONGs executivas (Fundabrinq, Instituto Ayrton Senna e ANDI) que instrumentalizam suas missões institucionais a partir de aparatos midiáticos (editoras, mobilização, advocacy, monitoramento de mídia, clipping, análises quantiqualitativas de noticiário da criança e do adolescente), baseadas no Jornalismo Público (jornalista como interventor na realidade cidadã, para muito além dos critérios de objetividade) e no interesse público. Esse agenciamento visa a implementação de políticas públicas a partir de critérios organizacionais dessas ONGs, que têm apoio de Unicef, Unesco e OIT. A autora trabalhou com material empírico de 104 textos veiculados na Folha de S. Paulo (no ano 2000) e 150 colunas, Criança (publicadas entre 1992 a 2004), parceria entre o jornal e a Fundabrinq. Esse é um dos primeiros trabalhos que têm uma visão positiva da infância e da adolescência, para muito além da tradição de pesquisa no tema, até então. Como resultado, F. Pereira (2005) considera que houve conformidade no tratamento à infância e à adolescência relativos ao ECA, doutrina da proteção integral, e que o estudo tem como constatação por parte das ONG's citadas que elas têm a 


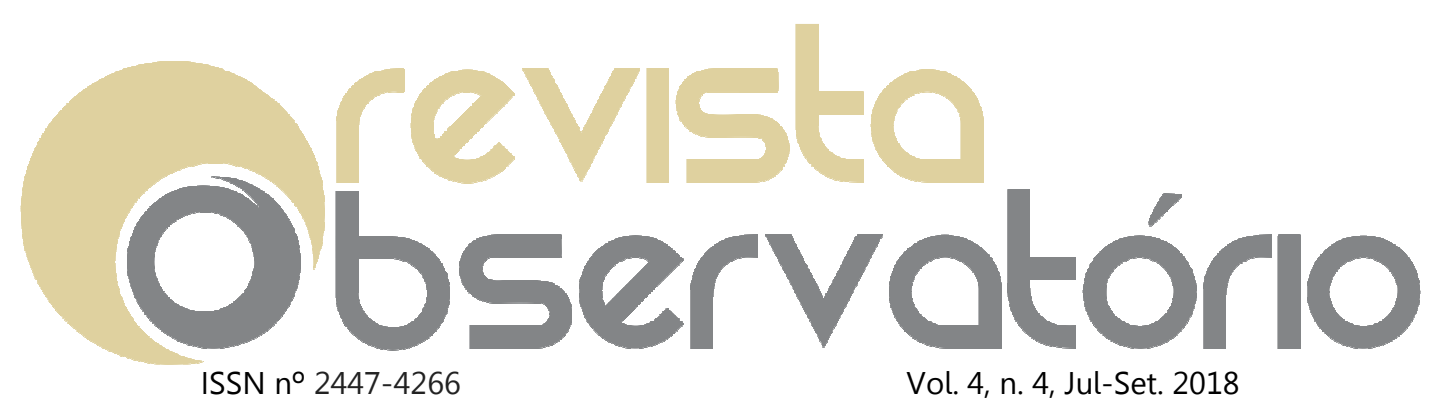

DOI: https://doi.org/10.20873/uft.2447-4266.2018v4n4p571

garantia de um espaço fixo para o tema da infância e da adolescência na Folha, mas, ao mesmo tempo, um espaço para a divulgação de projetos da Fundabring e dos parceiros da fundação (espaço mais publicitário), com textos que contribuem para reafirmar a noção de doadores (os empresários) versus beneficiados (os "cidadãos" receptores), ou seja, reforçam uma noção de cidadania nãoemancipadora, de gerenciamento e fixação de lugares sociais com apagamento da figura do Estado. (F. PEREIRA, 2005, p. 5)

No mesmo ano, Ribeiro (2005), em Jornalismo regional e construção da cidadania: o caso da Folha da Região de Araçatuba, dissertação em Comunicação, Universidade Estadual Paulista Júlio de Mesquita Filho (UNESP), também dá ênfase ao que, na época, existia a disputa conceitual em se nominar por Civic Journalism ou Jornalismo Público e ao arcabouço teórico do que convencionou chamar de Teorias da Notícia. Nessa orientação, citam-se: Câmara (2005), dissertação em Comunicação (PUCRIO), Bala perdida, falas perdidas: o discurso do jornalismo impresso sobre a morte de Gabriela Prado; Lessa (2005), dissertação em Comunicação (USP), Sexualidades na mídia jovem: informar, formar ou expor? : análise dos discursos sobre sexualidades na revista Capricho no período entre 1992-1993. E, por aproximação, Landini (2005), tese pela Sociologia (USP), Horror, honra e direitos. Violência sexual contra crianças e adolescentes no século XX, em como o noticiário constrói a figura da criança com base na concepção de dada época.

Bonfim (2005), em O papel das fontes na construção da notícia o agendamento do tema trabalho infantil doméstico no jornalismo impresso brasileiro, no ano de 2003, dissertação em Comunicação (UnB), se cerca de aparatos da própria área de Comunicação tentando não ser apenas aplicações, mas servir de base para teorização. Nesta época, havia uma discussão muito 


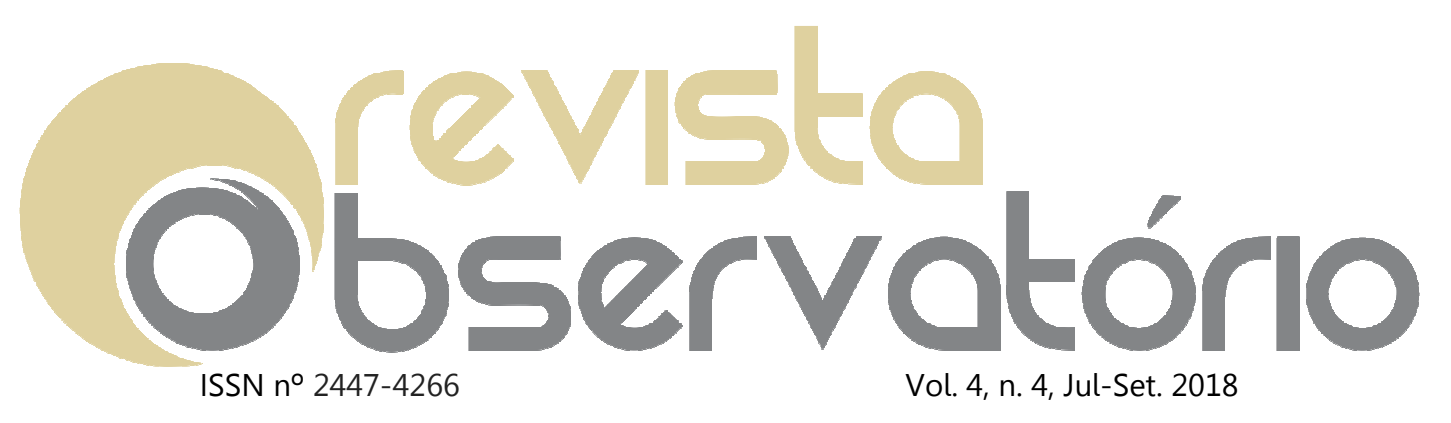

DOI: https://doi.org/10.20873/uft.2447-4266.2018v4n4p571

grande sobre o referencial de Civic Journalism e Jornalismo Cívico, que acabou sendo batizado de Jornalismo Público ${ }^{24}$, no Brasil; além da popularização de trabalhos de brasileiros sobre Comunicação Pública ${ }^{25}$, e ainda o que se convencionou chamar de Revolução das Fontes ${ }^{26}$ e Mídia das Fontes ${ }^{27}$. Assim como Lima (2005), Bonfim (2005) sai da sistematização do enquadramento da pauta, mas passa a discutir a construção de agenda da infância e da adolescência no país: sai de qual é a cara que se dá a esses personagens nas narrativas (produto jornalístico), para como são feitas essas narrativas (processo jornalístico), entendendo-as como processo de produção da notícia e cultura profissional jornalística.

É uma virada no perfil das abordagens, se comparadas ao que vimos da Educação, História, Sociologia, Biblioteconomia e Psicologia Social. Veja e perceba a discussão a partir de teóricos da área de Comunicação (Maxwell e MacCombs, Donald Shaw), além de estruturas de agenda, como o plano de comunicação:

\begin{abstract}
Entender o papel das fontes na construção social da notícia, relevando a sua importância como um dos fatores-chave na definição da Agenda Setting, a partir da relação sociedade civil organizada com 0 jornalismo impresso brasileiro, é o objetivo central deste trabalho. À luz dos conceitos de agendamento e enquadramento, o autor da pesquisa acompanhou, como observador participante, à época representando o Movimento Nacional de Meninos e Meninas de Rua, como seu assessor de imprensa, o desenvolvimento do Plano de Comunicação para o Enfrentamento do Trabalho Infantil Doméstico, que a Agência de Notícias dos Direitos da Infância (ANDI)
\end{abstract}

\footnotetext{
${ }^{24}$ Discussão que tinha autores, como: José Luiz Aidar Prado e Ayne Salviano, Alzira Alves de Abreu; Antônio Hohlfeldt; Carlos Álvarez Teijeiro; Carlos Castilho; Jan Schaffer; Luiz Martins da Silva; Márcio Ronaldo Santos Fernandes; Marialva Barbosa; Murilo César Soares, Nelson Traquina, dentre outros.

${ }^{25}$ Pierre Zemor, Elizabeth Brandão, Jorge Duarte, Wilson Bueno, Luiz Martins da Silva, Heloiza Mattos, dentre outros.

${ }^{26}$ Manuel Chapparo

${ }^{27}$ Francisco Sant'anna
} 


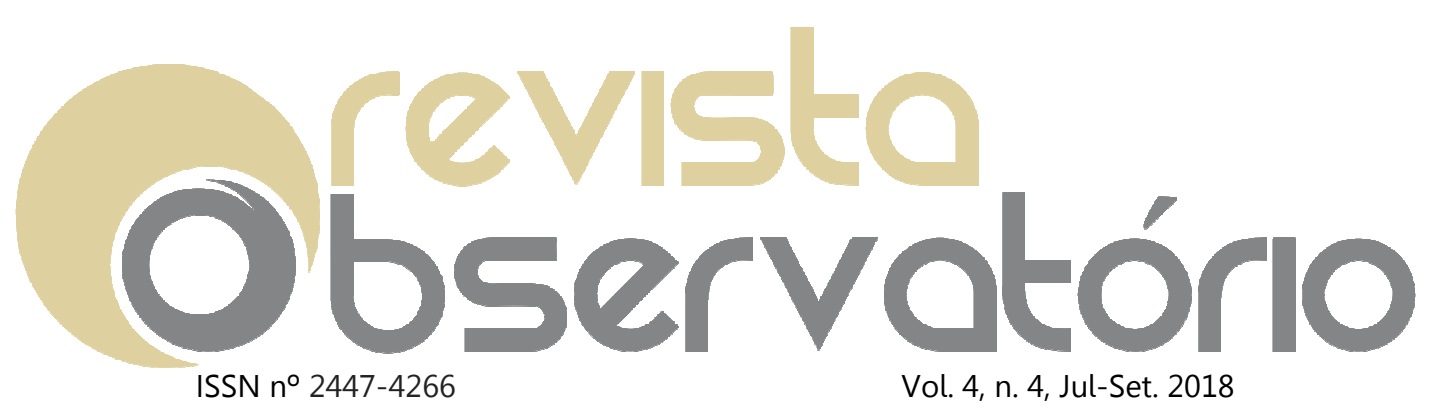

DOI: https://doi.org/10.20873/uft.2447-4266.2018v4n4p571

\begin{abstract}
desenvolveu, em parceria com outros organismos e financiado pela Organização Internacional do Trabalho (OIT), de 2002 a 2004, para dar ao tema Trabalho Infantil Doméstico visibilidade na mídia, em geral, e no jornalismo impresso em particular. As conclusões não deixam dúvidas de que não apenas houve o agendamento no jornalismo de um tema até então desconhecido da sociedade brasileira, como também, ocorreu o enquadramento do assunto nos grandes e pequenos jornais impressos do Brasil definido a priori pela ANDI, o que corrobora a idéia dos primary definers. Esta pesquisa conclui que é preciso colocar em xeque o poder do jornalismo, tão aclamado pela Teoria do Agendamento, retomando as questões colocadas por Maxwell E. MacCombs e Donald Shaw, pioneiros nos estudos do agendamento: "São os próprios media a estabelecer a agenda ou estes apenas refletem uma agenda estabelecida pelas suas fontes de informação?" (BONFIM, 2005, p. 5)
\end{abstract}

Recuperando: vimos que o olhar sobre veículos jornalísticos tradicionais (Segundo Setor), agora, também conviviam com novos trabalhos sobre a notícia produzida pelo Terceiro Setor. Rebechi (2002), Raposo (2005), F. Pereira (2005), Lima (2005) e Bonfim (2005). Dessas dissertações, todas são em Comunicação, a exceção de Rebechi (que é da História). Realmente, uma mudança de eixo e de abordagem em relação às três categorias aglutinadoras deste trabalho de estado da arte: criança, adolescente e noticiário. Podemos dizer, por excelência, que a partir deste momento se consolida um padrão de investigação na área, seja em pesquisas que investiguem com foco em Teorias do Jornalismo (Teorias da Notícia) ou em Comunicação (sentido lato), mas que tratem de notícia. E também que o padrão das pesquisas dos anos 1990 já se difere muito das dos anos 2000 .

Vale lembrar que o efeito multiplicador e institucionalizador da pesquisa em Comunicação e, principalmente, em Jornalismo nesse período com a criação 


\section{Observotório}

DOI: https://doi.org/10.20873/uft.2447-4266.2018v4n4p571

da Associação Brasileira de Pesquisadores em Jornalismo (SBPJor) ${ }^{28}$, que expande os fóruns qualificados que já existiam na Compós e no Intercom ${ }^{29}$.

A partir deste marco, da virada do perfil de abordagem do tema (1); do uso do arcabouço da Teoria da Notícia (2); da institucionalização de mais um fórum sobre jornalismo na SBPJor (3); da percepção da ANDI como protagonista na mudança de postura e tratamento da pauta na mídia (4); da chegada do arcabouço teórico de Jornalismo Público (Civic Journalism) no país (5); do desenvolvimento deste arcabouço por autores brasileiros e a equiparação dos assessores de imprensa aos repórteres das redações (6); do desenvolvimento do conceito de Comunicação Pública por autores brasileiros trazendo a questão do fluxo democrático da informação também para as organizações não-jornalísticas (7); do impacto das novas tecnologias e da estruturação das assessorias e veículos corporativos que passaram a produzir notícia de qualidade em pé de igualdade com as tradicionais redações do mercado noticioso $(8)^{30}$, todos esses 8 eventos por volta da metade dos anos

\footnotetext{
${ }^{28}$ Como visto no Quadro 2, trabalhos por região, a UnB leva o Centro-Oeste ao status de $3^{\circ}$ lugar no ranking do número de produções (critério regional). Isso também pode ser explicado pelo fato de que: a diretoria da SBPJor, 2003-2005, dos 13 da diretoria: 3 pesquisadores eram da UnB (23\%). Lembrando que, a SBPJor é a sociedade científica que mais promove o arcabouço da Teoria da Notícia, no Brasil, até por se concentrar nos estudos de Jornalismo (específico), muito mais do que os de Comunicação (sentido amplo). Esse caráter geográfico da UnB e desta geração também pode ser observado na cerimônia de fundação da SBPJor, também na UnB. Naquele primeiro biênio, participavam ainda da direção: UFBA, UnB, UFES, UFSC, USP, UFRGS, UFPE, UFRJ, UMESP.

${ }^{29}$ Aumentaram os fóruns qualificados para pesquisa em comunicação já existentes há décadas: nos anos 1960, Associação Brasileira de Comunicação Empresarial (Aberje); nos anos 1970, Sociedade Brasileira de Estudos Interdisciplinares da Comunicação (Intercom); nos anos 1980, Associação Brasileira de Jornalismo Científico (ABJC); nos anos 1990, Associação Nacional dos Programas de Pós-Graduação em Comunicação (Compós), Fórum Nacional de Professores de Jornalismo (FNPJ), Rede de Estudos e Pesquisas em Folkcomunicação (Rede Folkcom), além de Sociedade Brasileira de Estudos de Cinema e Audiovisual (Socine). Os estudos de Teoria da Notícia são promovidos e acolhidos de modo ostensivo pela SBPJor.

${ }^{30}$ Como desenvolvido na noção de Revolução das Fontes (Manuel Chaparro) e Mídia das Fontes (Francisco Sant'anna)
} 


\section{Observatório}

DOI: https://doi.org/10.20873/uft.2447-4266.2018v4n4p571

2000, são influentes e determinantes no começo de uma verdadeira profusão de novos estudos e problematizações de objetos de pesquisa sobre criança e adolescente no Brasil.

\section{8 - a multiplicação dos estudos do Agendamento ao Newsmaking}

O ano de 2008, assim como 2005, tem picos de produção sobre o tema em apreço. Também pode ser considerado um marco como etapa de multiplicação dos estudos, sendo as bases de pesquisa, majoritariamente, com foco na Teoria da Notícia e no Terceiro Setor. Sabemos que, por trás desses pesquisadores $^{31}$ há uma rede de professores e pesquisadores já experientes. Contudo, pelo formato deste trabalho e sua limitante em caracteres, não podemos aprofundar nos Grupos de Pesquisa, Projetos de Pesquisa, Linhas de Pesquisa, Áreas de Concentração, Iniciação Científica, livros, convênios, artigos em anais/atas de congressos ${ }^{32}$ ou mesmo em revistas, sem falar no efeito multiplicador e capacitador das monografias e iniciação científica (também relativas a matrículas: cursos) ${ }^{33}$, sem falar em estudos também comunicacionais,

\footnotetext{
${ }^{31}$ Matriculáveis, pois são estudantes de mestrado e de doutorado.

${ }^{32} \mathrm{Na}$ Comunicação, utilizando atuação a partir de artigos científicos, o Prof. Dr. José Luiz Aidar Prado (2002) já discutia $A$ construção da infância em Veja, em trabalho apresentado no Núcleo de Pesquisa Comunicação e Cultura das Minorias (NP13), XXV INTERCOM - Congresso Anual em Ciência da Comunicação, Salvador/BA, 04 e 05. Setembro de 2002.

33 Apenas para ilustrar: o Prof. Dr. Josenildo Guerra, UFS, por exemplo, teve um projeto de pesquisa neste período, Fontes de Informação na cobertura sobre a infância e a adolescência nos telejornais sergipanos (2004-2005), Infância em Foco (2003-2003), que, inclusive versava sobre estratégias jornalísticas da Rede Andi, ONG Cipó Comunicação Interativa (Bahia). O pesquisador multiplicou esse projeto em monografias com seus alunos de Iniciação Científica: Uma imersão nas instituições do sistema de garantia de direitos da criança e do adolescente: uma etnografia voltada para a qualificação do saber jornalístico na área temática infância $e$ adolescência, por Jéssica Vieira da Silva (2006), Fontes de Informação na cobertura sobre infância e adolescência nos telejornais sergipanos, por Wellington Nogueira Amarante e Ana
} 


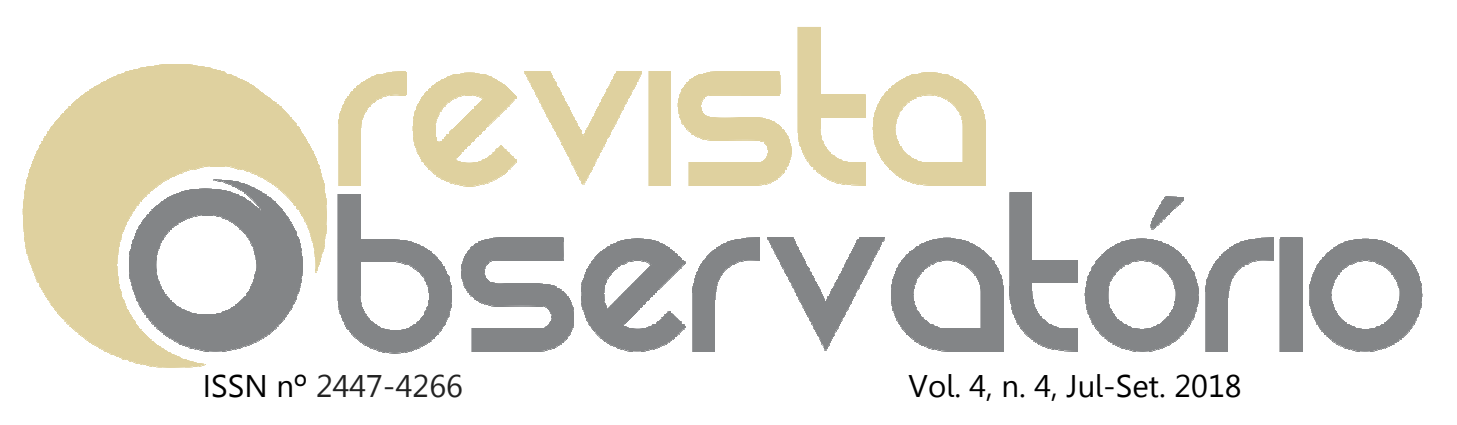

DOI: https://doi.org/10.20873/uft.2447-4266.2018v4n4p571

mas com viés na publicidade e consumo. São, inclusive, elementos que notificamos em rodapés para motivar novos estudos com esse levantamento.

Entre este trecho de virada do perfil das abordagens (2005) e o de franca multiplicação (2008), também citamos trabalhos que não podem ser esquecidos por não terem exatamente este novo perfil. Nesse sentido, recuperamos Brasiliense (2006), em Tessituras narrativas de o globo e o acontecimento "chacina da Candelária", dissertação em Comunicação (UFF), sobre as narrativas do jornal O Globo na cobertura da Chacina da Candelária (1993), além das inserções e debates deste evento em outras coberturas, como a do sequestro do ônibus 174 (2000). E também ressaltamos Nunes (2007), A criança e o adolescente na imprensa paulista (Jornal: Folha de São Paulo - 1990/2000), dissertação interdisciplinar em Educação, Administração e Comunicação Universidade São Marcos (USM), com análise da cobertura da Folha de S. Paulo, nas décadas de 1990 a 2000. Seguimos com J. Silva (2007), em Violência sexual doméstica contra crianças e adolescentes na imprensa (UFPE), é a primeira dissertação em Serviço Social a tocar o tema da criança, adolescente e noticiário. O estudo trabalha com a categoria violência sexual doméstica na imprensa pernambucana (Jornal Diário de Pernambuco e Jornal do Commércio do Estado de Pernambuco, 2002-2005) e é a segunda pesquisa a tratar do gênero feminino ${ }^{34}$.

Entrando na sequência do ano de 2008, temos Kraemer (2008), Entre o público e o privado: Interpretações sobre estórias de abuso sexual em narrativas jornalísticas $^{35}$, dissertação em Ciências Sociais (PUCRS), também traz a questão

Carolina Lima Santos (2005). As monografias e outras formas de produção científica não fazem parte do nosso escopo de teses e dissertações para este presente artigo.

${ }^{34}$ Precedida de Nazareth (2004), da Psicologia Social, PUCSP.

${ }^{35}$ Não detectado se é em Sociologia, Antropologia ou Política. 


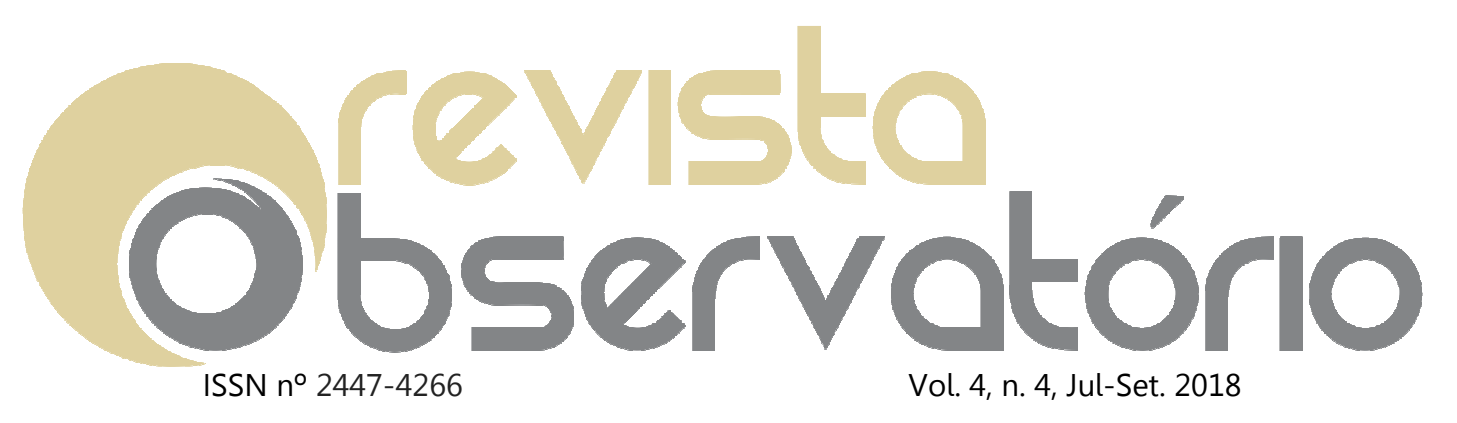

DOI: https://doi.org/10.20873/uft.2447-4266.2018v4n4p571

deste novo perfil a notícia do Terceiro Setor: "ANDI - um porta-voz no campo jornalístico" (KRAEMER, 2008, p. 13). A autora trabalha a discussão entre Espaço Público e Espaço Privado, muito comum na época, no Jornalismo, com a disseminação dos conceitos de Comunicação Pública, Jornalismo Público. Este trabalho também mostra a ANDI como objeto de estudo, no que concerne a efetividade desta ONG no agendamento na mídia: "indicadores que revelam a maior ou menor abertura dos jornais ao discurso da Agência de Notícias dos Direitos da Infância" (SILVA, 2008, p. 5).

Farah (2008), em Representações Visuais da Criança na Imprensa: uma análise dos jornais Folha de S. Paulo e O Estado de S. Paulo, dissertação em Comunicação, Universidade Tuiuti do Paraná (UTP), é o primeiro estudo a ter foco específico na linguagem e formato das fotografias jornalísticas, trazendo uma análise de aspectos verbais e não-verbais na estruturação da página impressa dos jornais (verbovisuais), com uma ênfase no que chamou de "estudos das teorias do jornalismo e da fotografia, e da semiótica discursiva e plástica" (FARAH, 2008, p.5).

A UnB contribui com 3 dissertações em Comunicação, Mora (2008), Oliveira (2008) e Dias (2008). Os três versam sobre agenda pública, agendamento, Contra-Agendamento, Newsmaking, Terceiro Setor, Advocacy, ANDI, Jornalismo Institucional e Jornalismo Público, com aporte também em Ação Comunicativa ${ }^{36}$, de Habermas. Mora (2008), em O Concurso Tim Lopes de

\footnotetext{
${ }^{36}$ A popularização das obras de Habermas, na Comunicação, também ajudaram na questão de se pensar 0 jornalismo pra além da racionalidade instrumental e abrir caminho para emancipação social via racionalidade comunicativa. Autores como Bárbara Freitag Rouanet, Luiz Carlos Aidar Prado, Wilson da Silva Gomes e Luiz Martins da Silva, dentre inúmeros outros, trabalharam muito nessa perspectiva a partir de processos jornalísticos e comunicacionais (a exceção da Bárbara, com um compromisso com a Sociologia e Filosofia, sendo professora emérita UnB; e visitante USP, UNESP, UFPR, UFBA). Até 2009, das obras originais de Habermas traduzidas para o português somavam 23 títulos (1980-2006), sendo a grande maioria (18 delas:
} 


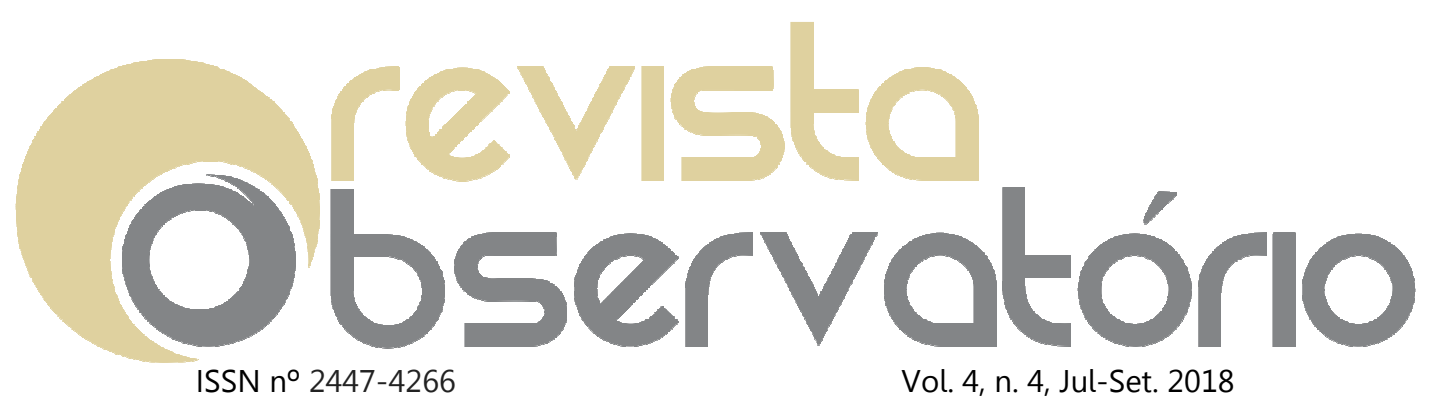

DOI: https://doi.org/10.20873/uft.2447-4266.2018v4n4p571

Investigação Jornalística como estratégia de agendamento da violência sexual contra crianças e adolescentes na imprensa brasileira, um estudo sobre a estratégia agendamento da violência sexual contra crianças e adolescentes por meio de um prêmio que financiava pautas candidatas ao fundo de produção de reportagens (teoricamente, tocava a hibridização de gêneros jornalísticos e tendências antitéticas: Agenda-Setting e Social-Setting, Valores-Notícia e Valores-Serviço). Dias (2008) também versou sobre uma premiação da ANDI, $A$ influência do prêmio Jornalista Amigo da Criança sobre o profissional de jornalismo: um estudo de caso, na qual identifica uma mudança de postura e cosmovisão na cultura profissional jornalística que passa a premiar o profissional e tornar esse indivíduo premiado em um ator social engajado no advocacy dos direitos da infância e da adolescência, tomando uma rede de 346 jornalistas aos quais aplicou um questionário, sob a perspectiva dos estudos de Newsmaking ${ }^{37}$. E Oliveira (2008), em Jornalismo para além do valor-notícia. O valor-convergente como modelo para selecionar e inserir temas sociais na mídia, teoriza, a partir da hipótese do Agenda-Setting, Contra-Agendamento e o que chamou de modelo de Agendamento Convergente. uma complexa relação entre porteiros selecionadores de notícias (gatekeepers), Jornalismo Investigativo, Advocacy, decisores públicos (Policy Agenda Setting), Valores-

78\%) editadas entra os anos 1990 e 2000, mais especificamente 6 livros nos anos 1990 (26\%, ou seja, $1 / 3$ da obra do autor pelas editoras Brasiliense, Tempo Brasileiro e Instituto Piaget) e 12 livros nos anos 2000 (52\%, ou seja, mais da metade do catálogo habermasiano disponível em português, pelas editoras Littera Mundi, Instituto Piaget, Martins Fontes, Tempo Brasileiro, Edições Loyola, Lisboa: Edições). Lembrando que Martins Fontes e Edições Loyola têm grande alcance de público e são de fácil acessabilidade, para muito além das editoras universitárias, reprografia e práticas similares de acesso ao conhecimento em suporte impresso.

37 Dias (2008) faz parte da geração de trabalhos, simultâneo à Santos (2008) e Pistolato (2008), precedidos por Azevedo (2003), que têm na sua metodologia a iniciativa de perguntar aos jornalistas o que eles acham da pauta da criança e da adolescência. Um perfil metodológico bem ligado à Newsmaking apoiado na análise de depoimento, etnografia, observação participante, pesquisa-ação, uso de questionários online, entrevista em profundidade, para muito além da análise documental. 


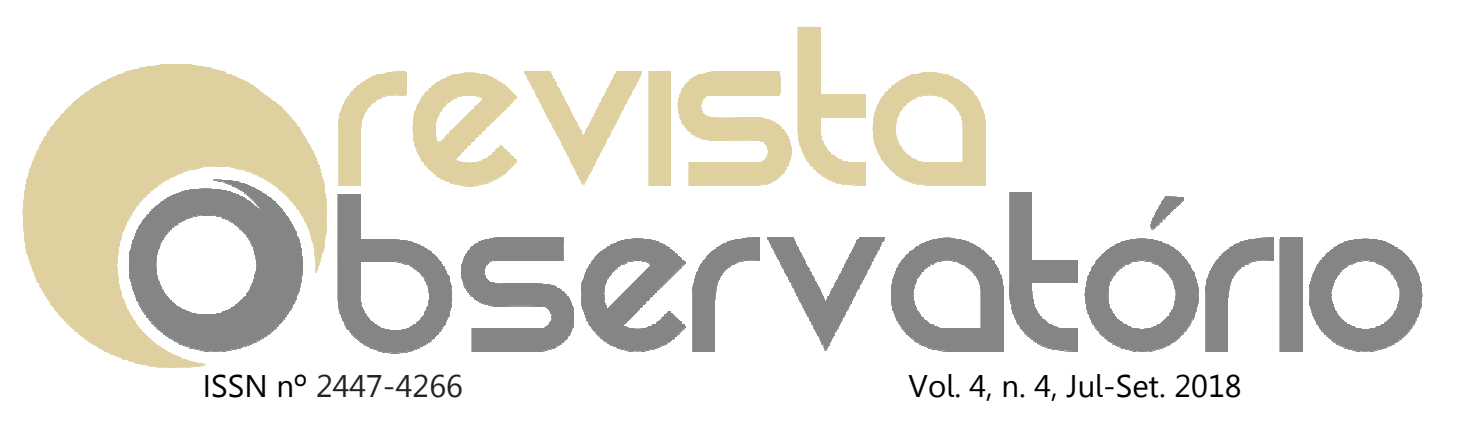

DOI: https://doi.org/10.20873/uft.2447-4266.2018v4n4p571

Notícia (News Values) e Valores-Sociais, reivindicando a indivisibilidade entre Valores-Notícia e Valores-Sociais no mesmo acontecimento, em vista da função social do Jornalismo. Segundo o autor, "o modelo significaria, portanto, mais do que um novo paradigma do "fazer jornalístico" (OLIVEIRA, 2008, p. 5).

Santos (2008), em O agendamento do jornalismo: um estudo de caso sobre a infância e adolescência em Pernambuco, dissertação em Comunicação (UFPE), também teve foco nas estratégias de agendamento sobre a infância e adolescência: "considerando a centralidade da comunicação nas instituições sociais como fator de força" (SANTOS, 2008, p. 5). No estudo, a autora trabalha também uma organização do Terceiro Setor (Auçuba Comunicação e Educação) buscando "identificar pistas sobre como esse assunto se incorpora nas práticas dos jornalistas e passa a fazer parte da agenda destes veículos" (IDEM). Metodologicamente, também vai a campo e tenta saber a opinião dos jornalistas e atores sociais quanto à pauta e rotinas produtivas, simultâneo a Dias (2008) e a Pistolato (2008).

Pistolato (2008), em $A$ influência da comunicação na erradicação das piores formas de trabalho infantil no Paraná: o Programa Catavento, dissertação em Comunicação, Universidade de Marília (UNIMAR), a partir de trabalho infantil (precoce) olha para o Terceiro Setor (Catavento Comunicação e Educação) e suas estratégias jornalísticas junto ao Espaço Público e Espaço Midiático. Também tem aporte na Ação Comunicativa, de Habermas ${ }^{38}$, além de ir à campo (entrevista em profundidade), tendo menos foco em pesquisa documental.

${ }^{38}$ Assim como Mora (2008), Dias (2008), Oliveira (2008). 


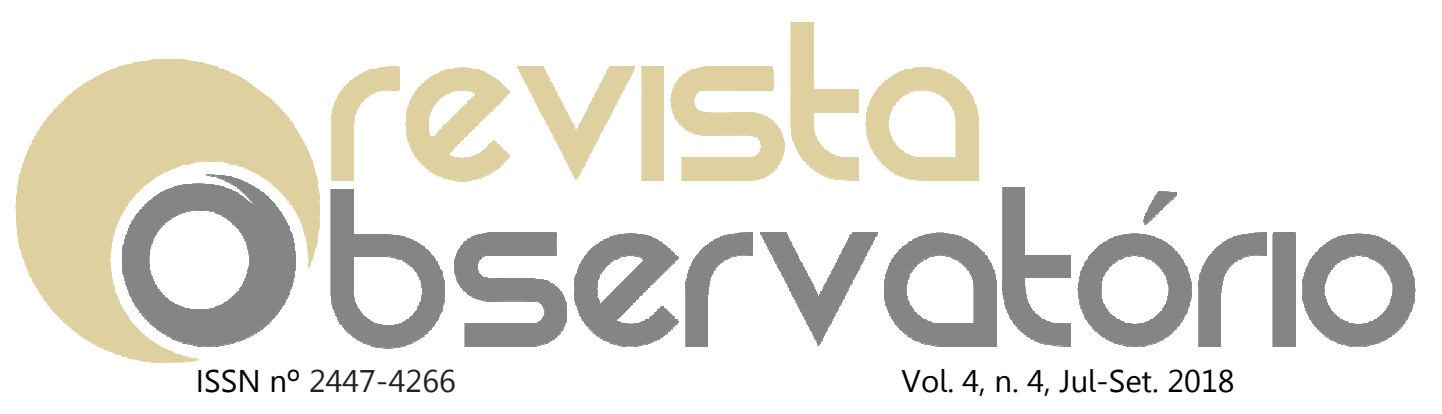

DOI: https://doi.org/10.20873/uft.2447-4266.2018v4n4p571

Extrapolando as abordagens da Teoria da Notícia do campo da Comunicação, Campos (2008), em $A$ infância sem segredos: a noticiabilidade jornalística do crime de exploração sexual de crianças e adolescentes, é a primeira dissertação das Ciências da Saúde ${ }^{39}$, desenvolvida no Departamento de Medicina (Programa de Saúde da Criança e do Adolescente, Faculdade de Medicina, UFMG $)^{40}$, mas tem como domínio a palavra-chave: noticiabilidade, em um PPG com área de concentração em Saúde da Criança e do Adolescente ${ }^{41}$. A partir de um corpus de 15 reportagens sobre o tema da exploração sexual infanto-juvenil, publicadas no jornal Estado de Minas (ao longo de 2004), a autora contempla momentos de seleção e produção das notícias, abordando o que ela chama de "tanto a forma estética da notícia" (CAMPOS, 2008, p. 5), que é "como a notícia se apresenta para o consumo do público - quanto os aspectos textuais determinantes na especificidade do relato noticioso" (IDEM). E demarca, mesmo nas Ciências da Saúde (em PPG da Faculdade de Medicina), o uso e "valorização das investigações sobre a noticiabilidade jornalística como uma importante metodologia de conhecimento do jornalismo e de seu funcionamento em sociedade" (IDEM), no que entende ser um aparato "apropriado para a discussão da produção da notícia e da forma como esse

\footnotetext{
39 Não entraremos no mérito de onde a Psicologia tem cadeira: saúde? sociais? sociais aplicadas? humanas? E polêmicas do tipo.

${ }_{40}$ Depois, publicaria em interface com pesquisadores do Programa de Saúde da Criança e do Adolescente, Faculdade de Medicina (1); Departamento de Comunicação Social, Faculdade de Filosofia e Ciências Humanas (2) e Departamento de Pediatria, Faculdade de Medicina (3). Todos da UFMG.

${ }^{41}$ A título de ilustração de trabalhos feitos pelo orientador de Campos (2008), Prof. Dr. Joaquim Antonio Cesar Mota, e médico, neste PPG, para muito além do trabalho de noticiabilidade em apreço: Doenças do fígado e das vias biliares na infância (1), Doenças do aparelho digestivo na infância (2), Terapia nutricional nas doenças do aparelho digestivo na infância e na adolescência (3), Aspectos biopsicossociais da saúde na infância e adolescência (4), Doenças Infecciosas na Infância e Adolescência (5), Diarréia aguda na infância (6), Avaliação do estado nutricional na infância (7).
} 


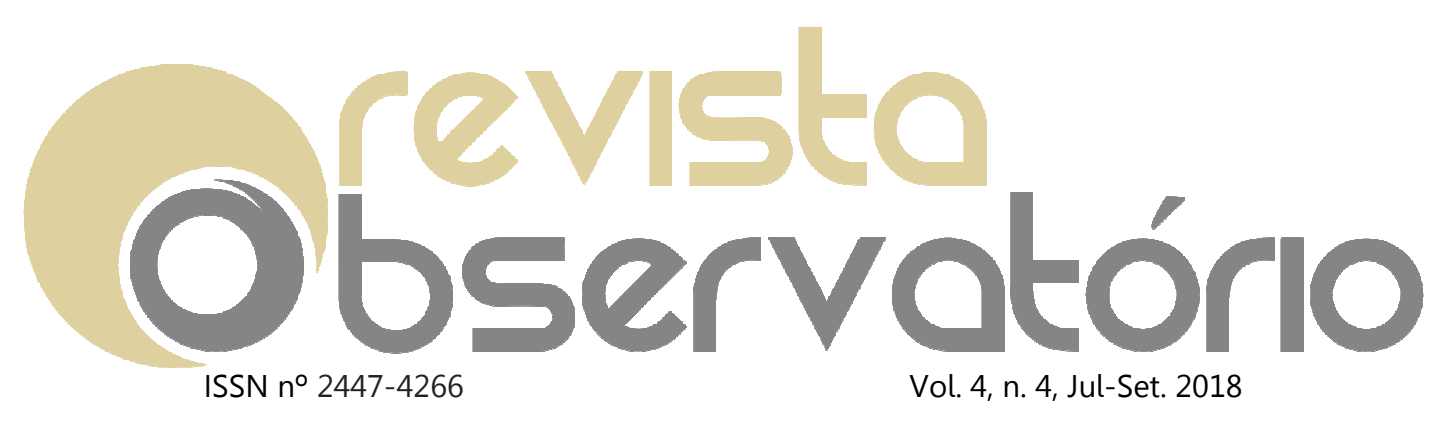

DOI: https://doi.org/10.20873/uft.2447-4266.2018v4n4p571

processo noticioso está irremediavelmente atracado ao segmento social, o qual o respalda e justifica na medida em que se reconhece nele" (IDEM).

Bizzo (2008), apesar de ser da Psicologia Social (e não da Comunicação), é a primeira dissertação a se interessar por corpus de noticiário online: Infância associada ao tema aborto voluntário em peças jornalísticas publicadas pelo jornal online da Folha de S. Paulo (1997-2005), PUCSP. A autora versa sobre um corpus de 298 matérias webjornalísticas da Folha de S. Paulo (1997-2005), em análise de conteúdo, sobre a categoria aborto voluntário, a partir da hermenêutica da profundidade, buscando associações entre infância e a adolescência e o tema do aborto voluntário (como pauta, seria o debate da descriminalização versus legalização do aborto) $)^{42}$.

Fechando a década, temos esse novo perfil de pesquisa em Anselmo (2009), A representação das práticas socioculturais de crianças e adolescentes do jornal boca de rua: a experiência do boquinha, dissertação em Comunicação, Universidade Federal do Rio Grande do Sul (UFRGS). E também em Cerqueira (2009), Jornalismo e exclusão social - Análise comparativa nas coberturas sobre crianças e adolescentes, dissertação em Comunicação (PUCRIO), que trabalha a categoria exclusão social na cobertura sobre crianças e adolescentes. Por fim, Reimberg (2009) como mais um trabalho a investigar jornais organizacionais, como o da Pastoral da Criança para a cidadania na Arquidiocese de São Paulo. na busca de como é representação da criança nesta publicação e que enquadramento de cidadania que é dado a esta figura. É o primeiro trabalho em Comunicação sobre um jornal organizacional contemporâneo, pois os outros eram da Educação: Assis (2004), Andreotti (2004). E versavam sobre

\footnotetext{
${ }^{42}$ As abordagens da Psicologia Social costumam não variar muito da opção pela hermenêutica de profundidade (busca por marcas ideológicas) e da análise de conteúdo (análise de massa documental).
} 


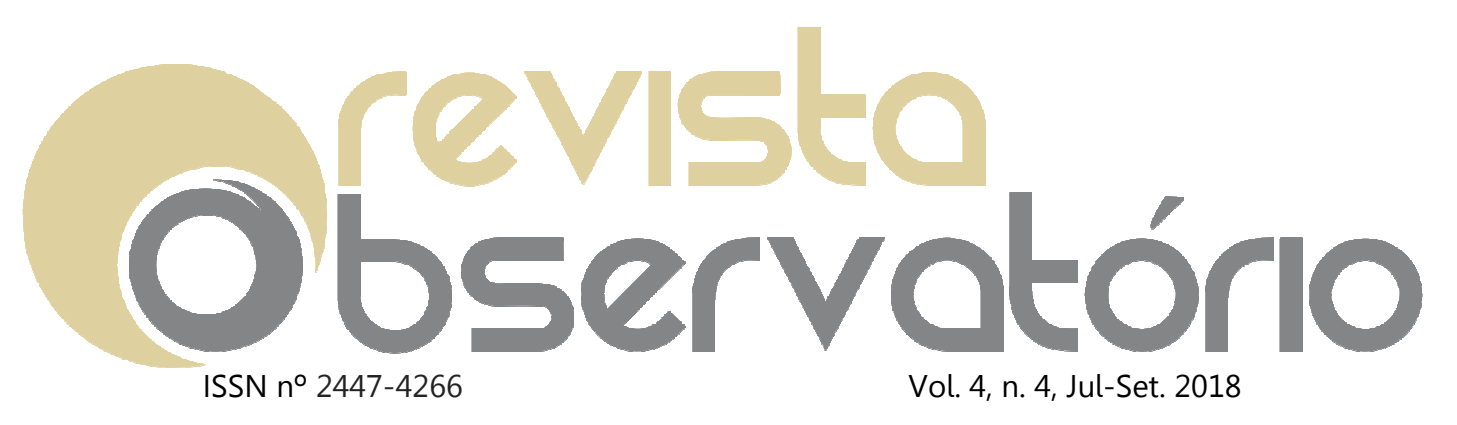

DOI: https://doi.org/10.20873/uft.2447-4266.2018v4n4p571

outras gerações e tempos históricos: Psicologia, educação e reforma dos costumes: lições da Selecta Cathólica (1846-1847); e A formação de uma geração: a educação para a promoção social e o progresso do país no jornal a voz da infância da biblioteca infantil municipal de São Paulo (1936-1950), respectivamente.

\section{Considerações Finais}

Como limitante, a pesquisa bibliográfica apenas avalia dissertações e teses produzidas no Brasil. Mas tem como oportunidade o foco em pesquisas matriculáveis, ou seja, onde os pesquisadores produzem em prol de um título acadêmico (diferentemente de grupos de pesquisa, projetos de pesquisa, publicações em revistas e livros). Durante a apuração, encontramos diversos esforços nessas outras vertentes que revelaram uma quantidade muito grande de monografias em graduações e especializações, além de iniciação científica com abordagens pertinentes ao escopo do tema dado neste estudo.

O estudo cumpre o seu objetivo em formalizar no formato artigo alguns apontamentos que podem levar tempo para o pesquisador não familiarizado ter acesso. Neste sentido, é importante que ele circule em bases indexadas dando condições a pesquisadores estrangeiros que queiram conhecer esse processo de institucionalização da pesquisa da criança e da adolescência no Brasil. Oportuniza estudos comparados e registra para a posteridade o esforço de gerações. Estamos em 2016 e o tema continua sendo problematizado em infinitas possibilidades de objeto de estudo. $E$ tende a se consolidar mais ainda em nível doutoral. Como vimos, nesta aplicação, nos anos 1990 e 2000, ficou patente o número vertiginoso de dissertações editadas: muitos desses 


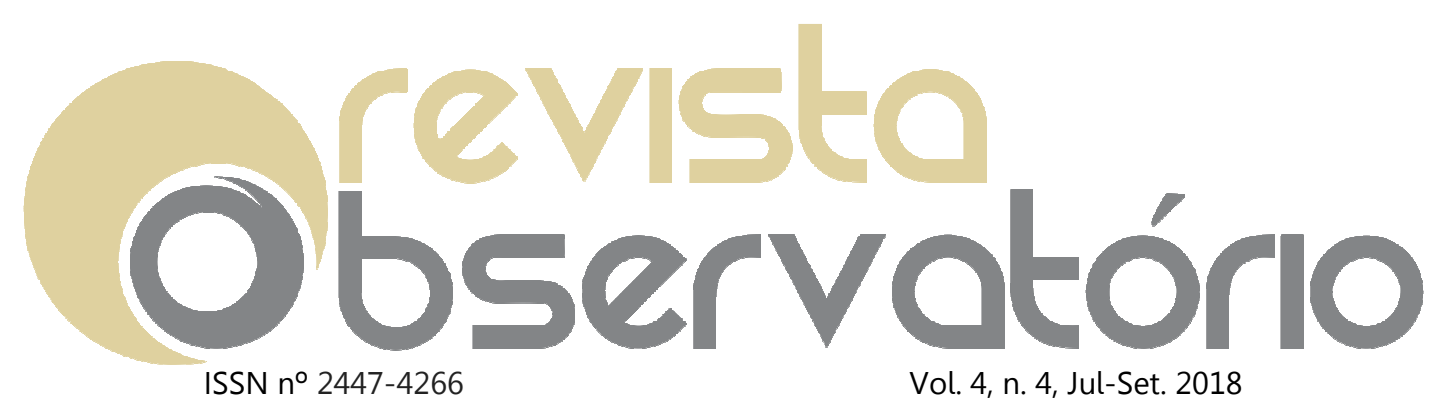

DOI: https://doi.org/10.20873/uft.2447-4266.2018v4n4p571

pesquisadores seguiram com novos trabalhos em teses. Na Psicologia, principalmente, já é patente o estudos da arte sobre o tema que toquem aquela área: Concepções de adolescência e trabalho em dissertações de psicologia social (2001-2011) (FERREIRA, 2014) e Exploração sexual comercial de crianças e adolescentes: o estado da arte nas produções acadêmicas em Psicologia (MELLO, 2010).

O Estado da Arte produz o status do conhecimento sobre um tema em dada área. Neste levantamento, tentamos fazer um inventário com a qualificação de um objeto (criança e adolescente no noticiário) e os esforços investigativos sobre este tema como um elemento da institucionalização da Pesquisa em Comunicação, em uma de suas inúmeras correntes e tradições. Não que estejamos fundando uma "corrente" ou "tradição" com esta revisão bibliográfica. Mas, sim, dando insumos para a pesquisa avançar cada vez mais neste tema. Pra nós, o mais importante é perceber a mudança de tratamento sobre o objeto e os esforços em sistematização científica feitos por pesquisadores de várias IES nacionais.

\section{Referências}

ANDI, Agência de Notícias dos Direitos da Criança. $\mathbf{O}$ grito dos inocentes - os meios de comunicação e a violência sexual contra crianças e adolescentes. São Paulo: Cortez. 2003

Agência de Notícias dos Direitos da Criança. 0 projeto. Disponível em http://www.andi.org.br/jac/o-projeto. Acesso em 10/10/2015

ANDRADE, Leandro. Prostituição infanto-juvenil na mídia: estigmatização e ideologia. Tese (Doutorado em Psicologia Social) - PUCSP. São Paulo, 2001

Marcelo. A categoria "meninos de rua" na mídia: uma interpretação ideológica. Tese (Doutorado em Psicologia Social), PUCSP. 2005 


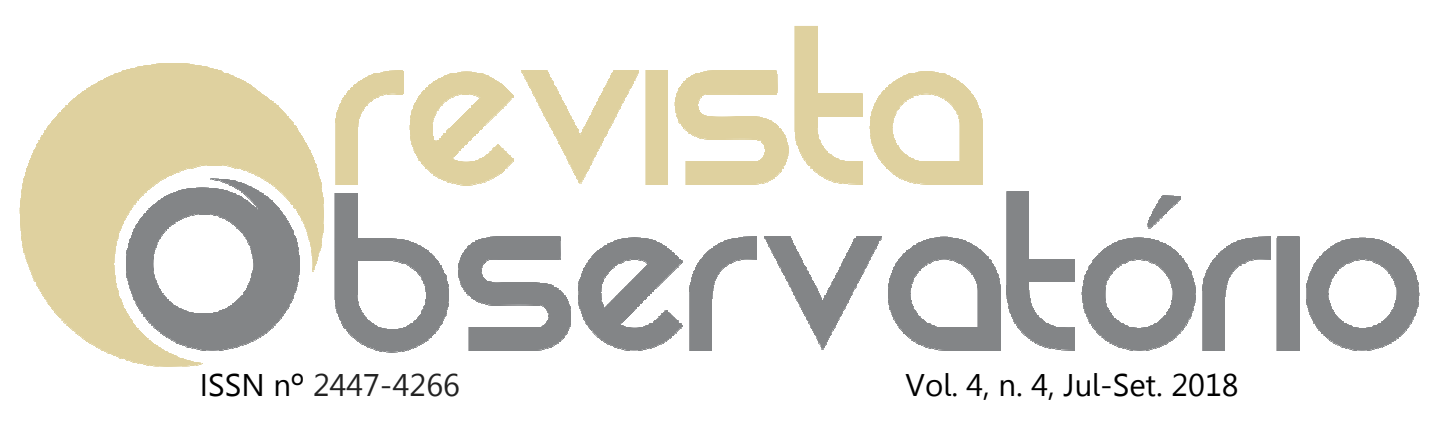

DOI: https://doi.org/10.20873/uft.2447-4266.2018v4n4p571

AZEVEDO, Maria. Trabalho infantil, movimentos sociais e imprensa: um olhar sobre o fazer jornalístico. Dissertação (Mestrado em Comunicação), USP. 2003

BASTOS, Martha. 0 movimento de defesa da criança e do adolescente: uma contribuição para sua análise. (Dissertação, Mestrado em Educação). UFF. 1995.

BIZZO, Vanessa Monteiro. Infância associada ao tema aborto voluntário me peças jornalísticas publicadas pelo jornal online da Folha de S. Paulo (1997-2005). (Dissertação, Mestrado em Psicologia Social). PUC/SP. 2008.

BONFIM, William. 0 papel das fontes na construção da notícia o agendamento do tema trabalho infantil doméstico no jornalismo impresso brasileiro, no ano de 2003. Dissertação (Mestrado em Comunicação), UNB. 2005

BRASILIENSE, Danielle. Tessituras narrativas de $\mathbf{0}$ Globo e o acontecimento "Chacina da Candelária". Dissertação (Mestrado em Comunicação), UFF. 2006

BRASIL. Lei n 8.069/90 (Estatuto da Criança e do Adolescente, ECA)

CÂMARA, Ana Letícia. Bala perdida, falas perdidas: o discurso do jornalismo impresso sobre a morte de Gabriela Prado. (Dissertação, Mestrado em Comunicação). PUCRIO. 2005

CAMPOS, Maria. A infância sem segredos: a noticiabilidade jornalística do crime de exploração sexual de crianças e adolescentes. Dissertação (Mestrado em Comunicação). UFMG. 2008.

CARVALHO, Sonia. A iconografia da AIDS: um estudo comparativo da comunicação impressa na prevenção à AIDS para o público adolescente no período de 1993 a 2007. (Dissertação, Mestrado em Comunicação). USP. 2009

CERQUEIRA, Vinicius. Jornalismo e exclusão social: análise comparativa nas coberturas sobre crianças e adolescentes. (Dissertação, Mestrado em Comunicação). PUCRIO. 2009

COSTA, Angela. 0 pão do corpo o pão da inteligência e o pão do coração o lugar da criança na sociedade 1927-1990. (Dissertação, Mestrado em História). PUCSP. 1996

COSTA, Mônica. Ler sem engasgar: dois tipos de recepção do jornalismo 


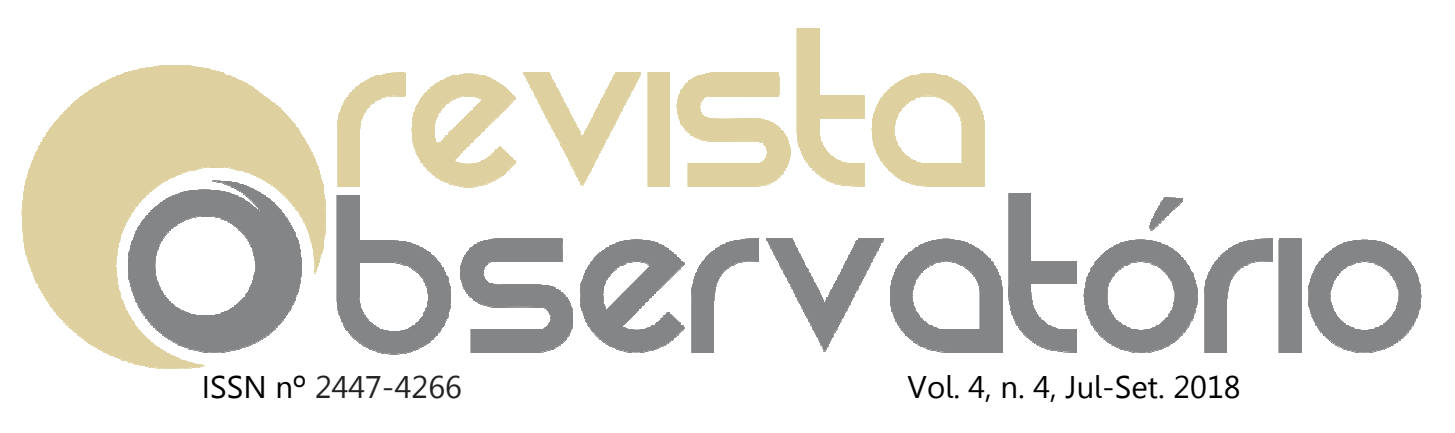

DOI: https://doi.org/10.20873/uft.2447-4266.2018v4n4p571

infantil da Folhinha - suplemento infantil da Folha de S. Paulo. (Dissertação, Mestrado em Comunicação). PUCSP. 1992.

DIAS, Robson. A influência do prêmio Jornalista Amigo da Criança sobre o profissional de jornalismo: um estudo de caso. (Dissertação, Mestrado em Comunicação). UnB. 2008

Robson. Prêmios em Jornalismo: Paradigmas em transição. (Tese, Doutorado em Comunicação), UnB. 2013

DUARTE, Mauricio. Cidadania obstruida: jornais cariocas e a construção discursiva da violência no Rio. Tese (Doutorado em Comunicação). UFRJ. 2003

ESCOVER, Maira. O tema sexo na revista Todateen: um estudo freudiano. (Dissertação, Mestrado em Comunicação). UNESP. 2005

FARAH, Angela Maria. Representações visuais da criança na imprensa: uma análise dos jornais Folha de S. Paulo e O Estado de S. Paulo. (Dissertação, Mestrado em Comunicação). UTP. 2008

FARAONE, Nadja. Temas de cidadania em jornais infantis - um estudo dos suplementos A Gazetinha, Diário Criança, Estadinho e Folhinha. (Dissertação, Mestrado em Comunicação). USP. 2001

FERREIRA (2014). Concepções de adolescência e trabalho em dissertações de psicologia social (2001-2011). (Dissertação, Mestrado em Psicologia Social). PUCSP. 2014

FREITAS, Rosângela. O tema trabalho infanto-juvenil na mídia: uma interpretação ideológica. Tese (Doutorado em Psicologia Social). PUCSP. 2004

FRONTANA, Isabel. Cotidiano de crianças e adolescentes nas ruas da metrópole paulistana: sob o fogo cruzado de posturas e opiniões (19641965). (Dissertação de Mestrado em História Social). USP. 1997

GIRARDELLO, Gilka. Televisão e imaginação infantil: Histórias da Costa da Lagoa. (Tese, Doutorado em Comunicação). USP. 1998

GUARNIERI, Ana Célia. Violência e imprens: o tratamento mediático da violência criminal juvenil. (Dissertação, Mestrado em Comunicação). USP. 2002 


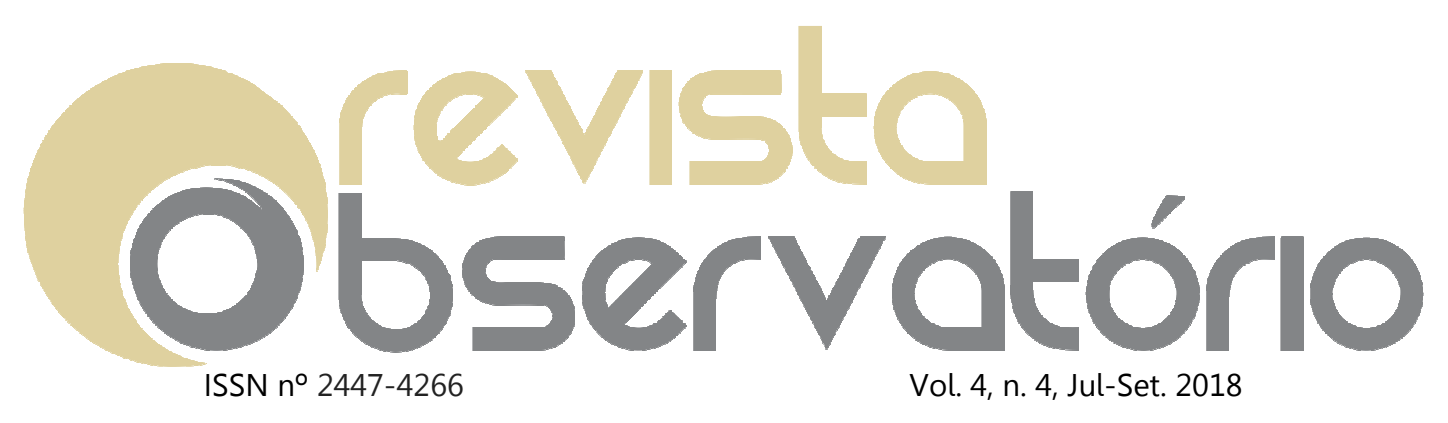

DOI: https://doi.org/10.20873/uft.2447-4266.2018v4n4p571

KRAEMER, Luciana. Entre o público e o privado: interpretações sobre estórias de abuso sexual em narrativas jornalísticas. (Dissertação, Mestrado em Comunicação). PUCRS. 2008

LANDINI, Tatiana. Horror, honra e direitos: violência sexual contra crianças e adolescentes no século XX. (Tese, Doutorado em Sociologia). USP. 2005

LESSA, Ana Cecilia. Sexualidades na mídia jovem : informar, formar ou expor? : análise dos discursos sobre sexualidades na revista Capricho no período entre 1992-1993. (Dissertação, Mestrado em Comunicação). USP. 2005

LIMA, Ines. Impacto da agenda social no jornalismo brasileiro - Agência de Notícias dos Direitos da Infância: uma experiência exemplar de Jornalismo Público. (Dissertação, Mestrado em Comunicação). UnB. 01/01/2005

MATTOS, Maria. Adolescência, mídia e ação comunitária. (Dissertação, Mestrado em Comunicação). UFRJ. 2000

MELO, Andréa. Olho na tela e pé no chão - Informação sobre meio ambiente, criança e internet. (Dissertação, Mestrado em Comunicação). USP. 2003

MELLO (2010). Exploração sexual comercial de crianças e adolescentes: o estado da arte nas produções acadêmicas em Psicologia. (Dissertação, Mestrado em Psicologia Social). UFRN. 2014

MENDES, Emerson. O jornal infantil interativo. (Dissertação, Mestrado em Comunicação). UNESP. 2002

MORA, Gabriela. O concurso Tim Lopes de investigação jornalística como estratégia de agendamento da violência sexual contra crianças e adolescentes na imprensa brasileira. (Dissertação, Mestrado em Comunicação). UnB. 2008

MOURA, Roberto. As meninas do mangue: uma psicologia da memória. (Dissertação, Mestrado em Psicologia). UFRJ. 1997

NAZARETH, Leila. $\mathbf{O}$ discurso da mídia sobre a adolescente grávida: uma análise da ideologia. Dissertação (Mestrado em Psicologia Social). PUCSP. 2004.

NUNES, Tania. A criança e o adolescente na imprensa paulista (Jornal: Folha de São Paulo - 1990/2000). (Dissertação, Mestrado Interdisciplinar em Educação, Administração e Comunicação). Universidade São Marcos. 2007 


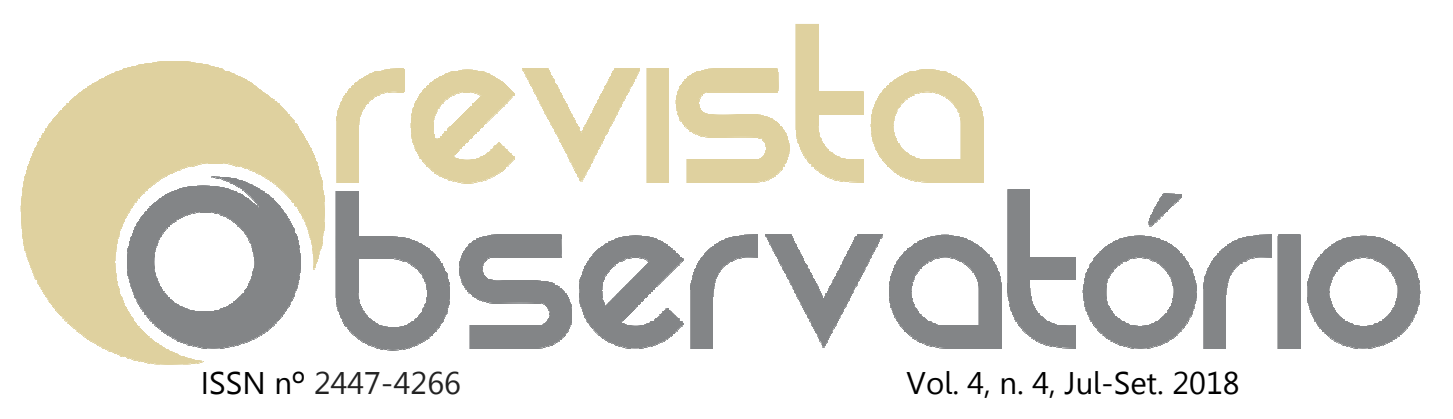

DOI: https://doi.org/10.20873/uft.2447-4266.2018v4n4p571

OLIVEIRA, Daniel. Jornalismo para além do valor-notícia. $O$ valorconvergente como modelo para selecionar e inserir temas sociais na mídia. (Dissertação, Mestrado em Comunicação). UnB. 2008

PEREIRA, Fabiana. Em nome da criança e do adolescente : ONGs e imprensa em parceria na construção do noticiário. (Dissertação, Mestrado em Comunicação). USP. 2005

PEREIRA, Maria. Representação social de pais e crianças com meningite bacteriana. (Tese, Doutorado em Ciências Médias). UNICAMP. 2001

PEREIRA, Manoel. Condenados à Juventude: Um estudo comparativo sobre a juvenilização no jornalismo brasileiro. (Dissertação, Mestrado em Comunicação). UnB. 2000

PRADO, Luiz. A criança, o jovem e sua permanente busca de identidades em tempos de novos meios e Pós-Modernidade. (Dissertação, Mestrado em Comunicação). UFG. 2009

PISTOLATO, Aneri. A influência da comunicação na erradicação das piores formas de trabalho infantil no Paraná: o programa catavento. (Dissertação, Mestrado em Comunicação). UNIMAR. 2008

RAPOSO, Maria. Comunicação virtual entre ONGs e construção do conhecimento - o caso da rede ANDI Brasil. Dissertação (Mestrado em Comunicação), UFPE.2005

REBECHI, Mônica. Agência de Notícias dos Direitos da Infância ANDI - Um Estudo Preliminar de uma Organização do Terceiro Setor. Dissertação (Mestrado em História), Mackenzie. 2002

REIMBERG, Cristiane. Comunicação, educação e saúde: a ação da Pastoral da Criança para a cidadania na Arquidiocese de São Paulo. (Dissertação, Mestrado em Comunicação). USP. 2009.

RUIZ, Lissandra. Gestão da informação: da criação à recepção. Estudo de caso : Revista Todateen - para público adolescente. (Dissertação, Mestrado em Comunicação). UNESP. 2005. 


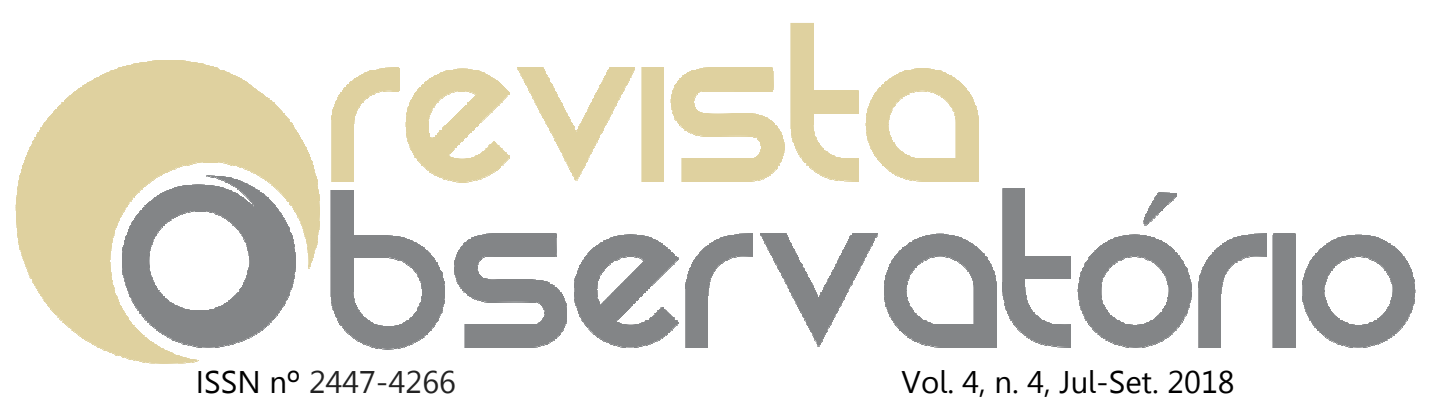

DOI: https://doi.org/10.20873/uft.2447-4266.2018v4n4p571

SAMPAIO, Inês Sílvia Vitorino. A tematização da infância nas esferas públicas mediáticas: uma análise centrada na propaganda de televisão. (Tese, Doutorado em Antropologia Social). UNICAMP. 1999

SANTOS, Cristiane. $\mathbf{O}$ agendamento do jornalismo: um estudo de caso sobre a infância e adolescência em Pernambuco. (Dissertação, Mestrado em Comunicação). UFPE. 2008

SILVA, Josenita. Violência sexual doméstica contra crianças e adolescentes na imprensa. (Dissertação, Mestrado em Serviço Social). UFPE. 2007.

Luiz Martins. Sociedade, esfera pública e agendamento. In: BENETTI, Márcia; LAGO, Cláudia. (Org.). Metodologia de pesquisa em jornalismo. 1 ed. Petrópolis: Vozes, 2007

SOUSA, Jorge Pedro. As notícias e os seus efeitos. As teorias do jornalismo e dos efeitos sociais dos media. Biblioteca On-Line de Ciências da Comunicação. 1999

2002.

Jorge Pedro. Teorias da notícia e do jornalismo. Chapecó: Argos,

SOUZA, Josinete. Da infância desvalida à infância delinquente: Fortaleza (1865-1928). Dissertação (Mestrado em História), PUCSP. 1999

Marina. Infância de papel: análise do discurso jornalístico sobre a infância na imprensa brasileira. Dissertação (Mestrado em Comunicação), UFRJ. 1999 TRAQUINA, N. (Org.) Jornalismo: questões, teorias e estórias. Lisboa: Veja, 1993. p.142-151.

TRINDADE, Judite. Metamorfose de criança para menor: Curitiba início do século XX. Tese (Doutorado em História). UFPR. 1998.

VIVARTA, Veet (coord.). Direitos, infância e agenda pública 2005-2007: uma análise comparativa da cobertura jornalística latinoamericana. Traduzido por Sandra Pérez. Brasília, DF: ANDI; RedeANDI América Latina, 2009, 64 p. Disponivel em: http://www.andi.org.br >. Acesso em: 18 set. 2015. 